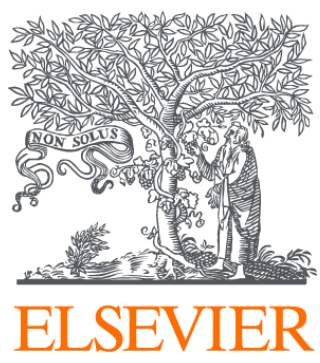

Since January 2020 Elsevier has created a COVID-19 resource centre with free information in English and Mandarin on the novel coronavirus COVID-

19. The COVID-19 resource centre is hosted on Elsevier Connect, the company's public news and information website.

Elsevier hereby grants permission to make all its COVID-19-related research that is available on the COVID-19 resource centre - including this research content - immediately available in PubMed Central and other publicly funded repositories, such as the WHO COVID database with rights for unrestricted research re-use and analyses in any form or by any means with acknowledgement of the original source. These permissions are granted for free by Elsevier for as long as the COVID-19 resource centre remains active. 


\title{
Respiratory Syncytial Virus
}

\author{
Olli Ruuskanen, MD \\ Pearay L. Ogra, MD
}

Respiratory syncytial virus (RSV) was first isolated in 1955 from a chimpanzee, and its infectivity in humans was documented the next year. It was named respiratory syncytial virus because of its characteristic ability to induce syncytia (i.e., multinucleate mass of protoplasm produced by the merging of cells) in tissue culture cells. It was soon recognized that RSV is a very common etiologic agent of childhood respiratory infections throughout the world. It has been estimated that in the United States every year 100,000 children are hospitalized and 2,000 young children die due to RSV infection.

Several features of RSV are characteristic. RSV is the most common causative agent of bronchiolitis and pneumonia, typically in very young children. The regular yearly epidemics are familiar to all clinicians. Immune mechanisms seem to play a key role in the development of severe RSV infection, but our understanding of the pathogenesis is still incomplete. The molecular structure of RSV is now well described, permitting studies with different viral proteins. There are two distinct groups of RSV and probably several subgroups. Molecular epidemiologic studies now in progress may answer the question of why repeated infections occur throughout life in spite of pre-existing RSV antibodies.

RSV can be detected from nasopharyngeal mucus by commercial tests within an hour, and specific antiviral chemotherapy with ribavirin is available.

Olli Ruuskanen, MD, is Chief, Division of Infectious Diseases, Department of Pediatrics, Turku University Hospital, Turku, Finland.

Pearay L. Ogra, MD, is John Seal Professor and Chairman, Department of Pediatrics, Children's Hospital, the University of Texas Medical Branch at Galveston, Galveston.
Recent studies suggest that $\beta$-adrenergic drugs may be beneficial in some patients with bronchiolitis. Several different approaches to develop a safe and effective vaccine are now in progress. ${ }^{1-8}$

\section{Agent}

RSV is a pleomorphic, enveloped, cytoplasmic virus containing single-stranded, negative-sense RNA. The RNA is associated with viral proteins, consisting of a nucleocapsid core that is packaged within a lipid envelope. RSV is classified in the genus Pneumovirus, which belongs to the family Paramyxoviridae. The Paramyxoviridae family also includes two other genera, Paramyxovirus (containing, e.g., parainfluenza virus types 1, 2, and 3 and mumps virus) and Morbillivirus. The genera are differentiated by the diameter of the helix, the number of genes, and the nature of their surface glycoproteins. ${ }^{9}$ The diameter of the RSV helix is 12 to $15 \mathrm{~nm}$. The surface G glycoprotein of the virus lacks neuroaminidase and hemagglutinin. The RSV genome contains 15,222 nucleotides. Complementary DNA (cDNA) cloning has identified ten different viral genes, each coding for a single protein. The sequences of each gene have been described. ${ }^{10}$ The characteristics of these genes differentiate RSV from the other members of Paramyxoviridae.

Eight of the ten RSV proteins are present in infected cells and in the virions, and therefore are structural proteins (Table 1). The disulfide-bonded glycoprotein ( $F$, fusion protein) and the large glycoprotein $(G$, attachment protein) are surface proteins and are the major antigenic determinants of the virus. They are the RSV proteins inducing neutralizing 
TABLE 1

Proteins of Respiratory Syncytial Virus Strain A2*

\begin{tabular}{|c|c|c|c|}
\hline Protein & $\begin{array}{l}\text { No. of Amino } \\
\text { Acids }\end{array}$ & Location & Function \\
\hline $\mathrm{G}$ & 298 & Envelope & Attachment to host receptor \\
\hline $\mathrm{F}$ & 574 & Envelope & $\begin{array}{l}\text { Viral penetration } \\
\text { Syncytium formation }\end{array}$ \\
\hline M & 256 & Envelope & $\begin{array}{l}\text { Inner lining of viral } \\
\text { envelope }\end{array}$ \\
\hline 22Kd (M2) & 194 & Envelope & $\begin{array}{l}\text { Inner lining of viral } \\
\text { envelope }\end{array}$ \\
\hline $\mathrm{N}$ & 391 & Nucleocapsid & Structural protein \\
\hline$P$ & 241 & Nucleocapsid & $\begin{array}{l}\text { Component of polymerase } \\
\text { complex? }\end{array}$ \\
\hline L & 2,165 & Nucleocapsid & Polymerase of nucleocapsid? \\
\hline $\mathrm{SH}(1 \mathrm{~A})$ & 64 & Surface of infected cells & Not known \\
\hline NS1 (1C) & 139 & Not in virion & Not known \\
\hline NS2 (1B) & 124 & Not in virion & Not known \\
\hline
\end{tabular}

${ }^{*}$ Modified from Chanock et al: Respiratory syncytial virus, in Evans AS (ed): Viral Infections of Humans. Epidemiology and Control, ed 3. New York, Plenum Medical Book Company, 1989, pp 525-544; and from Collins PL: The molecular biology of human respiratory syncytial virus (RSV) of the genus pneumovirus, in Kingsbury DW (ed): The Paramyxoviruses. New York, Plenum Press, 1991, pp 103-162.

and protective antibodies. The $G$ protein mediates viral attachment. The $\mathrm{F}$ protein mediates viral penetration and syncytium formation. In addition, the small hydrophobic protein $(\mathrm{SH})$, the matrix protein $(\mathrm{M})$, and the M2 protein are envelope-associated proteins. The nucleoprotein $(\mathrm{N})$, the phosphoprotein $(\mathrm{P})$, and the large nucleoprotein $(\mathrm{L})$ are present in the RSV nucleocapsid. NS1 and NS2 are nonstructural proteins; that is, they are found only in infected cells but not in virions. ${ }^{7,11}$

RSV was long considered to display minimal antigenic heterogeneity. However, two major groups of RSV, A and B, with antigenic differences on the $G, F, N$, and $P$ proteins, have now been identified. ${ }^{12,13}$ The viral groups can be identified with monoclonal antibodies against the major structural proteins, $^{12,13}$ by P-protein mobility analysis, ${ }^{14}$ by the nucleic acid hybridization technique, ${ }^{15}$ or by a polymerase chain reaction-based assay. ${ }^{16}$ The G protein is the most variable protein, with only $53 \%$ homology in the amino acid sequences between the proteins of the A and B groups. In contrast, the F and $\mathrm{N}$ proteins have a high degree of genetic and antigenic homology between the two groups. Both $F$ and $G$ proteins have several distinct antigenic sites.

Most recent data have shown considerable genetic diversity among groups $\mathrm{A}$ and $\mathrm{B}$. The Gprotein sequences may differ $20 \%$ in different group A lineages ${ }^{17}$ and $9 \%$ in different group B lineages. ${ }^{18}$ These are proposed to be called subgroups and are designated by numerals. ${ }^{19}$ Six subgroups within group A and three within group B have been described by Anderson and colleagues. ${ }^{20}$
The steps in the replication of RSV are schematically shown in Figure 1 . The virus attaches the cell through $G$ protein. The receptor is not known. The viral envelope fuses with plasma membrane of the host cell through $\mathrm{F}$ protein. After penetration, the nucleocapsid of the virus is released into the cellular cytoplasm, where the replication takes place. The viral RNA serves as a template for messenger RNA. The messenger RNA serves as a template for translation of viral proteins and complementary RNA serves as a template for transcription of virion RNA. ${ }^{3}$ The viral antigens can be demonstrated in 9 hours in cell culture and infectious virus, in 11 to 13 hours. Human RSV replicates in several animal species, including mice, rats, guinea pigs, ferrets, and chimpanzees. ${ }^{3,7}$

\section{Epidemiology}

Age

RSV is the only virus that preferentially induces severe respiratory infection during the first months of life. Primary RSV infection occurs most often between the age of 6 weeks and 2 years. The peak incidence of RSV bronchiolitis and pneumonia is between the ages of 2 and 6 months. RSV infection is rare in children less than 1 month old. ${ }^{21},{ }^{22}$ Recently, however, Avendano and colleagues ${ }^{23}$ from Chile reported on 239 patients with RSV infection, $28 \%$ of whom were less than 1 month old. In Rochester, New York, $70 \%$ of the hospitalized RSV patients were under 6 months old. ${ }^{6}$ In Australia, $90 \%$ of RSV 


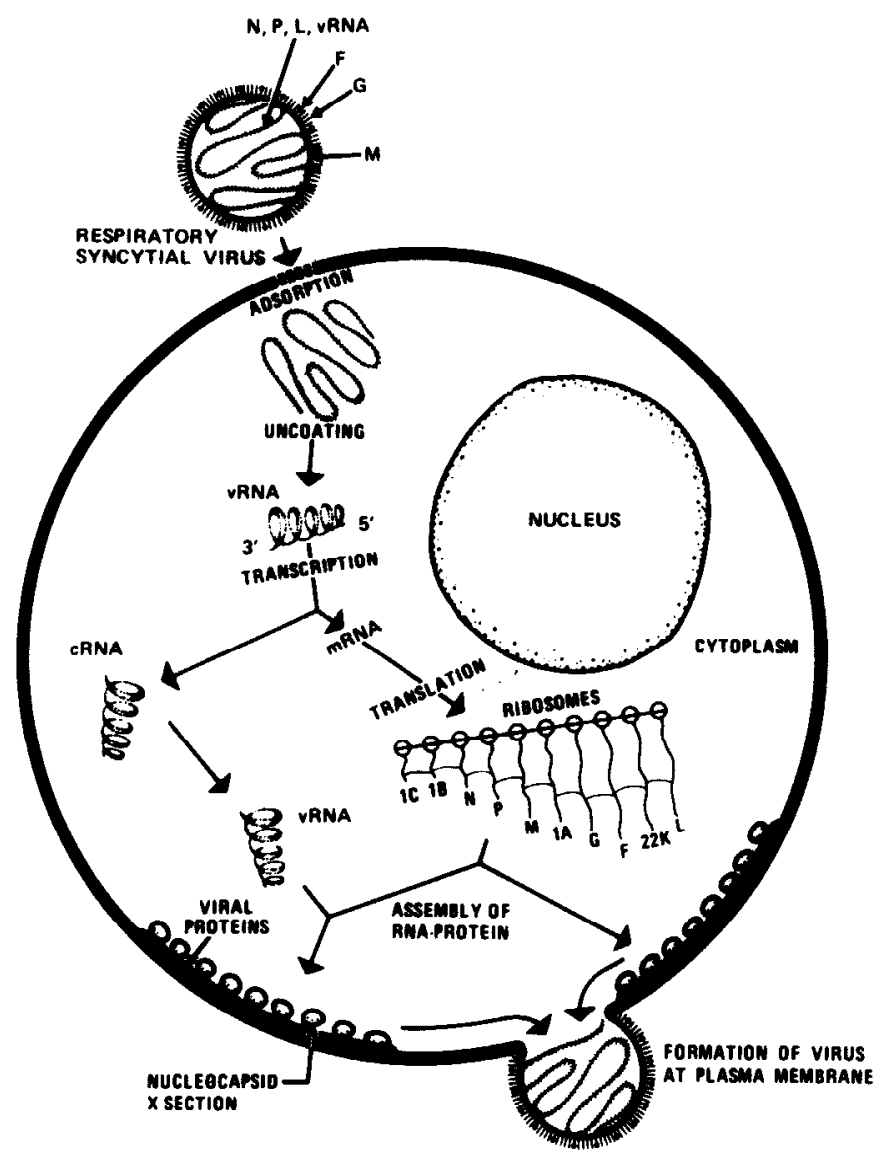

FIGURE 1

Schematic representation of the replication of respiratory syncytial virus. The letters indicate different viral proteins. $v R N A=$ viral RNA; $m R N A=$ messenger $\mathrm{RNA} ; c R N A=$ complementary RNA. (From Anderson LJ: Paramyxoviridae: Respiratory syncytial virus, in Lennette EI I, I Ialonen PH, Murphy FA (eds): Laboratory Diagnosis of Infectious Diseases. Principles and Practice, vol II. New York, SpringerVerlag, 1988, pp 540-570. Used by permission.)

detections were in children less than 1 year old. ${ }^{24} \mathrm{By}$ 3 to 4 years old, all children have been infected. ${ }^{25-27}$ During recent years, it has become evident that adults and especially elderly people have symptomatic RSV infections more often than reported earlier. Complement-fixing antibody for RSV has been documented in different studies in $33 \%$ to $99 \%$ of adults. ${ }^{5}$ Several epidemics in nursing-home patients and institutionalized young adults have also been reported. ${ }^{28}$

\section{Incidence and Prevalence}

Serologic studies in the 1960 s showed that about half of the infants are infected during their first RSV epidemic and almost all children, after their second RSV epidemic. A family study in Houston showed the infection rate to be $69 \%$ during the first year of life and $83 \%$ during the second year of life. Risk of re-infection was $33 \%$ during year $4 .{ }^{25}$ In a day-care center study the rate of infectivity was even higher. Of the seronegative children, $98 \%$ were infected during their first epidemic and $74 \%$ and $65 \%$ during their second and third epidemics, respectively. ${ }^{29}$ In a recent study from Sweden, $87 \%$ of children had RSV antibodies at the age of 18 months. ${ }^{26}$

In about $40 \%$ of patients with primary RSV infection, a lower respiratory tract infection may develop. ${ }^{30}$ In a prospective study of 1,179 infants in Tucson, the incidence rate for lower respiratory tract infection was 12 per 100 children in the first year of life. ${ }^{22}$ In Chapel Hill, bronchiolitis has been estimated to occur in $6 \%$ to $7 \%$ of children per year. ${ }^{31}$ There is less information from developing countries, but RSV also plays a major role there. ${ }^{27,}{ }^{32}$ Most incidence and prevalence figures are likely to be too low, since no study has included a combination of sensitive antigen detection assays, virus isolation, and sensitive IgG serology, which have all been shown to be necessary to obtain optimal detection of the RSV infection. ${ }^{33-35}$ In addition, many epidemiologic studies were carried out more than 20 years ago, when the viral detection techniques were less sensitive. For example, the conventional complement-fixation serologic test may detect only half of the RSV cases detected by enzyme-linked immunosorbent assay (ELISA). ${ }^{3,4}$

$\mathrm{RSV}$ is the most common etiologic agent to induce respiratory tract infection necessitating hospitalization. In studies in Turku and Wien, $49 \%$ and $55 \%$ of the hospitalized children with verified respiratory virus infection, respectively, had RSV infection. ${ }^{36,37}$ One of 100 primary infections leads to hospital admission. ${ }^{22,} 38$ It has been estimated that almost 100,000 children in the United States experience yearly RSV infection requiring hospitalization. ${ }^{25}$

\section{Seasonal Occurrence}

RSV infection has a clear-cut epidemic nature throughout the world. In temperate climates it usually occurs yearly during the fall and winter. It usually begins in the late fall and peaks in November to March. ${ }^{39}$ The epidemic lasts 5 to 6 months and peaks during the third or fourth month (Fig 2). Thus the actual month of peak infection varies a little from year to year. The intervals between peaks may be short or long. The spread of the epidemic is slower and the duration is shorter than that of influenza $\mathrm{A}$, which also induces winter epidemics. Only very rarely is RSV found during the summer.

This pattern of RSV infection has been consistent in most countries over the last 20 to 30 years and variations are rare. In Finland, RSV has ap- 


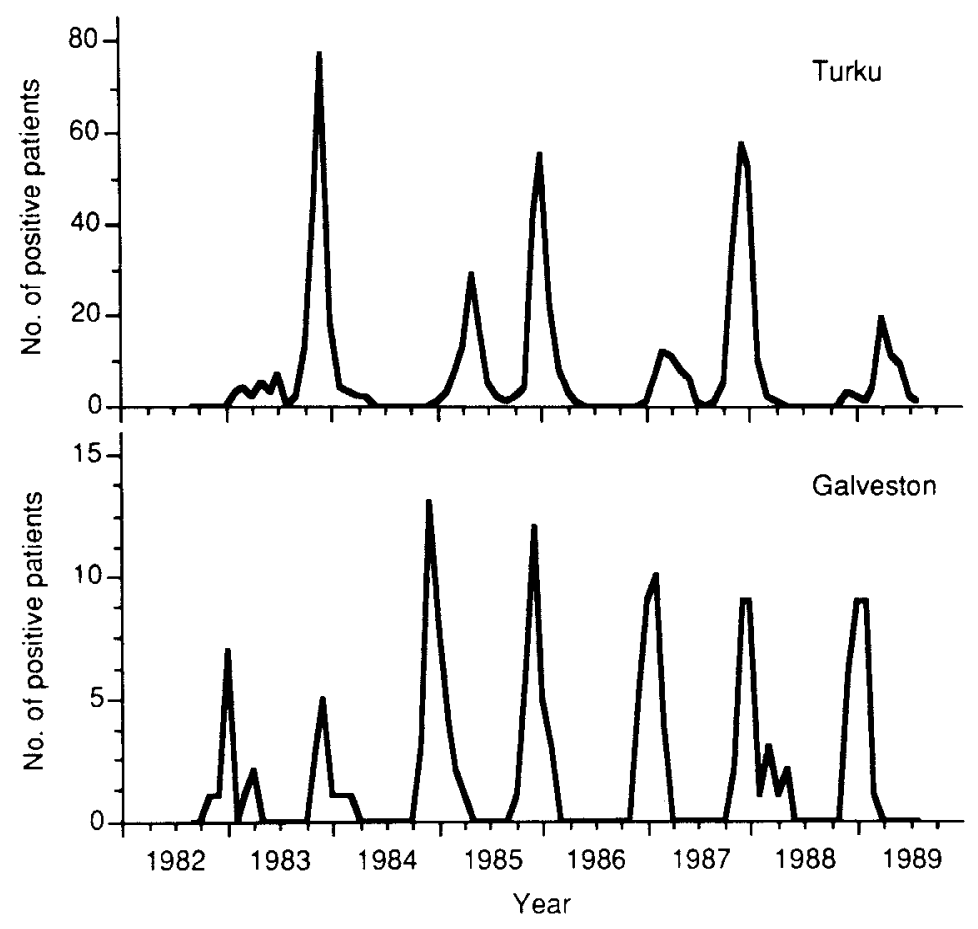

FIGURE 2

Numbers of hospitalized patients by month with respiratory syncytial virus infection in Turku, Finland, and Galveston, Texas, during 1982 to 1989.

peared during the 1980s in double-humped outbreaks, with a small outbreak occurring during the late spring and a second major outbreak during the following autumn (see Fig 2). ${ }^{40}$ Hence, the major RSV epidemics in Finland have occurred in 2-year cycles. In Australia, RSV epidemics occur each year, with a peak in June to August with some variation. ${ }^{24}$ In tropical countries, RSV outbreaks coincide with the rainy season. ${ }^{41}$ The occurrence of RSV epidemics is inversely related to temperature and to the number of hours of sunshine. ${ }^{42}$

There are now many epidemiologic studies of group A and B RSV infections in the United States and other countries. Monto and Ohmit ${ }^{43}$ showed that the two RSV groups existed in one community since at least 1965. In almost all epidemics, groups A and $B$ have been found. The occurrence of outbreaks with predominantly group A RSV or predominantly group B RSV has varied according to the year and country studied. ${ }^{44}$ Many studies have shown that different groups can predominate in different geographic locations during the same year. A study from 14 laboratories in the United States and Canada found $63 \%$ of 483 RSV isolates to be within group A and $24 \%$ within group B. ${ }^{20}$ Furthermore, six subgroups within group A and three within group B were demonstrated. Six subgroups of group A were isolated during the same RSV season in the same laboratory. The predominance of group A RSV infections may be explained by the findings that group A virus induces greater protection from subsequent group B infection than the converse. ${ }^{45}$

Storch and colleagues ${ }^{19,46}$ showed that widespread genetic variation of the G-protein gene occurs between group A strains obtained from a single epidemic. However, strains obtained from the same family were identical. In agreement, Cane and colleagues ${ }^{47,48}$ showed by nucleic acid sequencing that multiple lineages of group A RSV co-circulate in a single epidemic and in different parts of the world. On the other hand, viruses isolated from different parts of the world at similar times may also be virtually identical.

\section{Transmission}

RSV infections are transmitted by large droplets, through fomite contamination, or by direct contamination with infected secretions. Close contact appears to be necessary for infection to spread from one person to another. In one study, no one sitting at a distance of greater than $1.8 \mathrm{~m}$ from RSV-infected infants became infected. ${ }^{49}$ The most important route of transmission appears to be self-inoculation with fingers contaminated with infected secretions. The virus can persist in a viable form on cloth gowns and paper tissue for 45 minutes, and on counlertops for 
up to 6 hours. ${ }^{49}$ The fingers transmit the virus to the nasal mucosa or conjunctivae, from where the virus spreads to the upper respiratory tract. The incubation period is usually 2 to 8 days (median, 5 days) ${ }^{6}$ The infection spreads to the lower respiratory tract within a few days of the onset of symptoms. The mechanisms of spreading are not well understood. Viremia has not been described in normal subjects, but viral antigens have been found in circulating blood mononuclear cells. RSV is secreted in nasopharyngeal secretions usually for 5 to 10 days. ${ }^{50,51}$ In a recent study, ${ }^{35} 40 \%$ to $60 \%$ of the patients stopped shedding RSV 8 to 10 days after the onset of illness (Fig 3). Some infants can shed RSV for up to 3 or 4 weeks or longer. Longer periods of virus shedding have been noted in immunosuppressed children, and shorter durations in older children and adults. ${ }^{50}$ RSV infection spreads actively in closed environments. In a family study, RSV infected $46 \%$ of the family members. ${ }^{50}$

\section{Risk Factors}

Several risk factors for RSV lower respiratory tract infection have been described. In the early months of life, the infection is more common in males. Furthermore, RSV infection is more common in children born during the summer months approximately 6 months before the outbreak, in those sharing a bedroom with other children (especially when there are two or more sharing the room), in day-care settings, and in infants of mothers with lower educational levels. ${ }^{21,22,52-54}$ Importantly, breast-feeding for longer than 1 month has a protective role, especially for those infants of mothers with lower socioeconomic status. Infants with a low titer of RSV antibody in cord serum and minimal breast-feeding are especially at risk for RSV infection of the lower respiratory tract. ${ }^{22}$

The role of atopic predisposition to severe RSV infection is controversial; some studies demonstrated significantly higher risk in children with atopy compared to control children, ${ }^{55}, 56$ while other studies showed no significant associations with atopy. ${ }^{53,57} \mathrm{~A}$ recent study showed that diminished lung function is a predisposing factor for lower respiratory tract infection associated with wheezing. ${ }^{58}$ This finding would explain why decreased pulmonary function has been recorded after RSV bronchiolitis. Many studies have shown that maternal smoking increases the risk of all respiratory virus infections. ${ }^{52,59-61}$ McConnochie and Roghmann ${ }^{60}$ showed that maternal smoking was associated with an increase in frequency of wheczing from $36 \%$ to $60 \%$. Thus, prolonging breast-feeding for longer than 1 month and cessation of parental smoking should be encouraged to reduce the risk of lower respiratory tract infection in infants and children.

\section{Pathogenesis}

Despite the large number of studies on the pathogenesis of RSV infection in humans and experimental animals, the current information is fragmentary

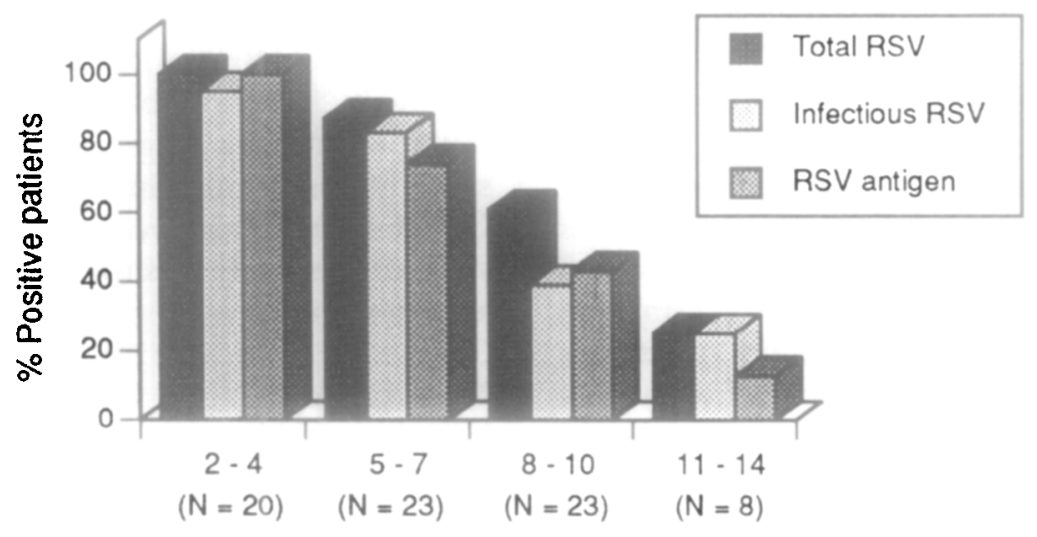

Days after onset of infection

FIGURE 3

Shedding of respiratory syncytial virus (RSV) in hospitalized children. Infectious RSV was demonstrated using immunoperoxidase staining and/or by observation of the specific cytopathic effect in infected cultures. RSV antigen was detected by direct timeresolved fluoroimmunoassay. Total RSV reflects both infectious RSV and RSV antigen. (Modified from Waris M, et al: J Med Virol 1992; 38:111-116. Used by permission. Copyright (C) 1992 Wiley-Liss. Reprinted by permission of Wiley-Liss, a division of John Wiley and Sons, Inc.). 
and the mechanisms of the disease are not well understood. ${ }^{62-67}$ Studies in humans have been difficult to undertake because the infection occurs most frequently in young infants with extremely low mortality. In vitro studies with human peripheral blood mononuclear cells as well as those with nasopharyngeal specimens have produced numerous observations, but only limited data are available on the immune response in the lower respiratory tract. Several animal models have been developed, but in most species the infection is asymptomatic. Nevertheless, many clinical findings and sophisticated animal experiments suggest a key role of immune response to RSV in the pathogenesis of the infection. There appears to be a delicate balance between immunopathology and immunoprotection. A precise understanding of the mechanisms of protection against infection, development of disease, and recovery from illness is needed for development of improved therapies and an effective and safe vaccine.

\section{Antibody-Mediated Immunity}

RSV infection induces incomplete immunity to disease, even after multiple infections. The primary infection, which often involves the lower respiratory tract as bronchiolitis or pneumonia, occurs most commonly in infants at 6 weeks to 6 months, when transplacentally derived maternal IgG antibodies still exist in the circulation. These universal observations suggest that serum IgG antibodies to RSV may not be protective. One hypothesis is that maternal antibodies react with the virus in the lung, inducing immune complex-mediated pulmonary injury. However, this hypothesis has been challenged by observations that RSV bronchiolitis occurs in infants without detectable RSV antibodies. Furthermore, bronchiolitis is rare in neonates less than 6 weeks old, who have the highest serum concentrations of maternally derived antibodies. New laboratory studies, however, have shown that antibodies to $F$ and $G$ surface glycoproteins can enhance the in vitro infection of human macrophages. This phenomenon may in part explain the disease process in bronchiolitis. ${ }^{68,69}$ In in vitro experiments, RSV plus anti-RSV antibody complexes may stimulate macrophages to produce leukotriene $C_{4}$ $\left(\mathrm{LTC}_{4}\right)$, which induces bronchospasm. ${ }^{70}$

The failure of transplacentally acquired RSV antibodies to protect against natural infection is not fully understood. It has been suggested that either maternal IgG may not contain enough IgG3 subclass antibodies, the antibodies against appropriate RSV group or subgroups may be insufficient, or the circulating IgG antibodies may not transudate to the mucosa of the lower respiratory tract. ${ }^{71}$ Recent studies have shown sequence diversity among the $G$ proteins within groups A and B RSVs. If the immune response is also subgroup specific, infection by one subgroup could occur despite the presence of neutralizing antibodies specific to another subgroup. ${ }^{18,} 19$

Another finding that has confused understanding of the pathogenesis of RSV infection is that the children vaccinated in the early 1960 s with a formalininactivated RSV candidate vaccine were not protected against the RSV infection, and paradoxically developed a more severe illness when exposed to natural infection. Such vaccination induced high concentrations of neutralizing and complement-fixing antibodies, and these may have reacted with the natural virus to induce harmful effects. Later, however, serum samples of the vaccinated children were reanalyzed and found to contain a large proportion of antibodies directed against nonprotective viral epitopes. These results suggest that formalin treatment altered the antigenic determinants of RSV, resulting in an aberrant host immune response. The large number of nonprotective antibodies in the serum could have formed complexes with viral antigens and induced pulmonary disease. ${ }^{72}$

There is, however, good epidemiologic evidence to suggest that high titers of maternal RSV antibodies can be protective against severe RSV-associated respiratory illness. ${ }^{21,22}$ Lamprecht and colleagues $^{73}$ found that maternal neutralizing antibody did not prevent infection but the severity of pneumonia was inversely related to the level of neutralizing antibody. High neutralizing, $F$ and $G$ antibody levels have also been found to correlate significantly with protection, but the protection is not complete. ${ }^{74}$ Recent studies on mice depleted of B cells showed that mice without antibody demonstrate enhanced histopathology in the lung and have more severe RSV infection than mice with intact B-cell function. These results support the view that antibody has an illness-sparing function in RSV infection. ${ }^{75}$ However, antibody was not needed for termination of RSV replication after primary infection. Connors and coworkers $^{76}$ found that $F$ and $G$ protein-induced antibodies are sufficient to mediate the resistance to RSV in the absence of $\mathrm{CD}^{+} \mathrm{T}$ cells, $\mathrm{CD}^{+} \mathrm{T}$ cells, and interferon- $\gamma$. On the other hand, the resistance induced by the $\mathrm{M} 2$ protein was mediated by $\mathrm{CD} 8^{+} \mathrm{T}$ cells and to some extent $\mathrm{CD}^{+}{ }^{+} \mathrm{T}$ cells and interferon- $\gamma$.

Further evidence of the possible protective effects of serum antibodies has come from trials of therapeutically administered, RSV-specific IgG in infants with RSV disease. Treated patients had enhanced clearance of the virus from the upper respiratory tract and improved clinical response, compared to placebo-treated control subjects. ${ }^{77-79}$ These 
observations agree with the results of animal studies showing that lung infection by RSV can be prevented by administration of high titers of neutralizing antibodies.

RSV-specific secretory IgA appears in the nasopharynx as early as the first 3 days after the onset of symptoms of infection and often peaks between 8 and 13 days. ${ }^{80}$ McIntosh and colleagues ${ }^{81}$ found that the appearance of RSV-specific secretory IgA in the nasopharynx coincided with the termination of RSV shedding, suggesting that secretory IgA may play a role in the termination of infection. Similar findings were recently obtained by Waris and coworkers. ${ }^{35}$ Specific nasal RSV antibody titers are not, however, found to correlate significantly with protection, although subjects with detectable nasal IgA antibody tended to become infected less often after challenge. Interestingly, one patient with secretory $\operatorname{Ig} A$ deficiency resisted the challenge with RSV. ${ }^{74}$

Studies performed in children with RSV bronchiolitis, or pneumonia with and without wheezing or subclinical infections, have shown that most virusinfected subjects develop RSV-specific IgE antibodies. ${ }^{82,83}$ However, only patients with wheezing manifest prolonged, cell-bound, virus-specific IgE response and free RSV-specific IgE in their nasopharyngeal secretions. Furthermore, the occurrence of RSV-specific IgE has been associated with subsequent episodes of virus-induced wheezing. ${ }^{84}$ In addition, the development of RSV-specific IgE correlated with increased concentrations of histamine in nasopharyngeal secretions of patients with bronchiolitis. ${ }^{82}$ The development of virus-specific IgE response may be constitutionally determined in patients with virus-associated bronchospasm. Caswell and associates ${ }^{85}$ reported more histamine release in response to RSV in those with bronchiolitis than in control subjects. This release would reflect latent sensitization to RSV antigens during bronchiolitis. The mechanism effecting histamine release could involve RSV-specific, IgE-inducing mast cells, basophils, and eosinophils. Increased plasma levels of histamine and a stable prostaglandin (PG) metabolite in bronchiolitis were also reported by Skoner and colleagues. ${ }^{86}$ They found a direct correlation between plasma levels and disease severity. In general, the children who had had bronchiolitis had higher levels of histamine and prostaglandin metabolite than normal children, even when asymptomatic. Chonmaitree and colleagues ${ }^{87}$ demonstrated that RSV can induce blood mononuclear cells to produce histamine-releasing factor in vitro. The development of RSV-specific IgE antibodies and increased histamine levels in both serum and secretions have also been demonstrated in calves infected with bovine RSV. This animal RSV infection model has many striking similarities in pulmonary pathology to human RSV infection. ${ }^{88}$

\section{Cell-Mediated Immunity}

Clinical and experimental studies suggest an important role for cell-mediated immunity in RSV infection. Severe and prolonged RSV infection has been observed in immunodeficiency states. ${ }^{89}$ Different T-cell subtypes, degrees of lymphocyte proliferation, and cytotoxic $T$-cell responses have been reported during and after RSV infection. Welliver and coworkers ${ }^{90}$ found fewer suppressor $T$ cells in patients with bronchiolitis during convalescence than in patients with other forms of illness due to RSV. These observations suggest that virus-induced or immunoregulatory defects may induce increased IgE production in patients with bronchiolitis. On the other hand, Domurat and colleagues ${ }^{91}$ found that in vitro RSV infection resulted in an increase in the number of suppressor $\mathrm{T}$ cells and a decrease in helper $\mathrm{T}$ cells.

RSV-induced lymphocyte proliferation, an in vitro correlate of cell-mediated immunity, has been observed to be high in RSV bronchiolitis and in other RSV-infected infants with bronchospasm, ${ }^{92}$ but contrary results have also been reported. ${ }^{93}$ The major target structure for $\mathrm{T}$-cell proliferation is the $\mathrm{F}$ protein of RSV, and lymphocytes responding to its antigenic sites have the characteristics of helper $\mathrm{T}$ cells. ${ }^{94}$ Clinical follow-up studies have suggested that alterations in RSV-specific lymphoproliferative activity may result in an increased tendency toward airway reactivity during subsequent re-infection with RSV. ${ }^{92}$ In vitro infection of mononuclear leukocytes with RSV has been shown to decrease the response of the cells to mitogens. ${ }^{95}$ Both $\mathrm{CD} 44^{+}$and $\mathrm{CD}^{+} \mathrm{T}$ lymphocytes have been shown to be involved in terminating RSV infection in a mouse model. Both of these cell types also contributed to the illness, suggesting that host immune response is the primary determinant of the disease. ${ }^{96}$

The peripheral blood lymphocytes of infants with acute RSV infection may exhibit cellular cytotoxic response against RSV-infected cells. ${ }^{97}$ The response appears to depend on age, and increases in infants over 6 months old. ${ }^{98}$ The development of cellular cytotoxic responses may play a role in the mechanisms of protection or immunologic injury that accompany RSV infection in humans. Studies in mice have demonstrated that passive transfer of RSV-specific cytotoxic $T$ cells can clear RSV from the lungs, but also intensify clinical symptoms, enhance pulmonary pathology, and increase death rate. ${ }^{99} \mathrm{Re}-$ cently, Munoz and colleagues ${ }^{100}$ demonstrated cylo- 
toxic cell lines capable of protecting lungs from RSV infection without producing an increase in morbidity and mortality. These observations strongly suggest that major histocompatibility complex (MHC) class I-restricted cytotoxic $T$ cells have an important role in clearing RSV from the lungs.

A series of studies using recombinant vaccinia viruses expressing different RSV proteins have shown in mice that the RSV-specific cytolytic T-cell response is specific for viral protein. The major target is a membrane-associated $22 \mathrm{Kd}$ protein followed by intermediate recognition of $\mathrm{F}$ or $\mathrm{N}$ proteins. ${ }^{101,102}$ Interestingly, the $22 \mathrm{Kd}$ RSV protein does not induce detectable RSV-specific antibodies in mice. ${ }^{103}$

\section{Inflammatory Mediators and Cytokines}

There is increasing evidence that RSV infection can result in the release of mediators and cytokines from target cells. Early studies clarified the role of interferon in RSV infection. RSV was found to be a poor inducer of interferon- $\alpha$ in vitro and in vivo, in contrast to other viruses such as influenza $A$ virus. ${ }^{104,} 105$ The concentrations of interferon- $\alpha$ in nasopharyngeal secretions do not correlate with the severity of illness. ${ }^{106}$ In vitro production of interferon- $\alpha$ is reduced during RSV bronchiolitis, and returns to normal after illness. ${ }^{107}$

RSV antibody complexes can activate the arachidonic acid pathways of human neutrophils in vitro. ${ }^{108}$ Most RSV-infected patients have high levels of $\mathrm{LTC}_{4}$ in the respiratory tract during the acute phase of infection. LTC $_{4}$ is an arachidonic acid metabolite that can cause bronchoconstriction. The levels in wheezing subjects appear to be significantly higher than in nonwheezing subjects. Furthermore, LTC $_{4}$ was detected more often in patients who developed an RSV-IgE response than in patients who did not. ${ }^{64}$ Garofalo and associates ${ }^{109}$ found LTC $_{4}$ in $83 \%$ of patients with bronchiolitis, and $\mathrm{LTD}_{4}$ and $\mathrm{LTB}_{4}$ in about $30 \%$. The mean partial arterial pressure of oxygen was lower in those with detectable $\mathrm{LTB}_{4}$ than in those without, suggesting that $\mathrm{LTB}_{4}$ may have an important role in the pathogenesis of bronchiolitis. $\mathrm{LTB}_{4}$ is an effective chemoattractant for neutrophils and eosinophils. A further study by Garofalo's group ${ }^{110}$ showed that concentrations of eosinophil cationic protein in nasopharyngeal secretions were significantly higher in RSV bronchiolitis than in RSV infections without wheezing, and the concentrations correlated with the severity of the disease. Eosinophil cationic protein is considered to have a major role in the pathogenesis of asthma and these findings lend further support to the hypothesis that asthma and virus-induced respiratory infection with expiratory wheezing are pathogenetically related.
RSV has been shown to induce interleukin-1 (IL-1) and IL-1 inhibitor production by human mononuclear leukocytes. The net effect is inhibition of IL-1 activity. ${ }^{111,112}$ Further studies showed suppression of intercellular adhesion molecule-1 (ICAM-1) and lymphocyte function-associated antigen (LFA-1) by human mononuclear leukocytes comparcd to the degree of expression induced by influenza virus. ${ }^{113}$ These phenomena may result in cell cycle arrest of virus-specific lymphocytes and may in part explain the recurrence of RSV infection in immune individuals.

Tumor necrosis factor (TNF)- $\alpha$ can be detected in serum from patients with RSV-induced lower respiratory tract infection. ${ }^{114}$ However, the concentrations are low, possibly because RSV has only minimal effects on the production of TNF by blood mononuclear phagocytes in vitro. In contrast, RSVinduced alveolar macrophages produce significant amounts of TNF. ${ }^{115}$ Panuska and coauthors ${ }^{115}$ suggested that TNF produced by alveolar macrophages may play a critical role in limiting pulmonary RSV infection, because TNF has antiviral activity. These observations agree with those of Becker and colleagues ${ }^{116}$ who demonstrated that RSV infection of human alveolar macrophages resulted in the production of TNF, IL-6, and IL-8. They suggested that through cytokine production, alveolar macrophages may have an important role in limiting RSV infection in the bronchoalveolar region of the lung.

Platelet-activating factor (PAF) is an important mediator in asthma. It has several biologic effects in various parts of the immune system. Recently, Villani and coworkers ${ }^{117}$ demonstrated that RSV infection in a human monocytic cell line induced the synthesis of PAF.

\section{Pathology}

RSV infects respiratory epithelial cells. In addition, human blood mononuclear cells and human alveolar macrophages have been shown to be infected with RSV. ${ }^{91,118}$ Organ systems outside the respiratory tract do not become infected in patients with normal immune systems. However, in immunocompromised patients, RSV has been recovered from the liver, spleen, and myocardium.

There is little or no information about the pathologic changes associated with RSV in mild pneumonia and bronchiolitis. Autopsy studies have revealed lymphocytic peribronchial infiltration in bronchiolitis. ${ }^{119}$ There was no cellular infiltration of alveolar tissue. Because RSV is attracted to respiratory epithelium, proliferation and necrosis of the epithelium develop. With the immunoperoxidase method of antigen detection on formalin-fixed, paraffin-embedded 
lung tissue, RSV antigen was demonstrated in epithelial cells from throughout the lower respiratory tract. ${ }^{120}$ Many RSV-positive cells had paranuclear eosinophilic inclusions. Edema can be found in submucosal and adventitial tissues. All these changes induce an obstruction of small airways by cellular debris, making expiration of air difficult and resulting in hyperinflation. Marked disturbances in respiratory mechanisms develop. An increase in respiratory resistance and a pronounced reduction in forced expiratory flow have been reported. ${ }^{121}$ In pneumonia, interalveolar walls are infiltrated with mononuclear cells and are thickened. Extensive pneumonic consolidation by alveolar debris containing protein, macrophages, epithelial cells, and numerous syncytial multinucleated giant cells with eosinophilic cytoplasmic inclusions have been found. ${ }^{120,122}$ RSV antigen has been investigated in two children with fatal bronchiolitis. Little virus was found in the lungs. By contrast, in a child with RSV-associated pneumonia, large amounts of viral antigen were detected. ${ }^{123}$

\section{Clinical Features}

The clinical picture of RSV infection varies according to the age of the patient. The primary RSV infection at the age of 6 weeks to 2 years is usually symptomatic and involves the lower respiratory tract. Asymptomatic primary RSV infection in children is rare. Repeated infections in older children are usually less severe. Table 2 shows the clinical spectrum of 2,903 RSV infections in hospitalized young children in several different countries. Respiratory tract infection associated with expiratory wheezing (i.e., bronchiolitis, wheezy bronchitis, and asthma; 52\%) and pneumonia $(21 \%)$ were the most common clinical manifestations. RSV infections in neonates differ from those in older children; apnea may be the only symptom of infection. Acute otitis media is the most common bacte- rial complication. The mortality in healthy children is extremely low, but life-threatening infections are common in immunocompromised patients and in patients with cardiac abnormalities. Pneumonia is the most common manifestation in elderly people.

\section{Upper Respiratory Tract Infection}

Isolated upper respiratory tract infections associated with RSV have been noted, especially in older children and adults during re-exposure. The common symptoms are rhinorrhea, nasal congestion, pharyngitis, and cough. ${ }^{50,127,128}$ RSV infection is a less febrile illness than other respiratory infections. ${ }^{129}, 130$ RSV-induced upper respiratory tract infection cannot be clinically differentiated from upper respiratory tract infections induced by other respiratory viruses. ${ }^{131}$ Some studies, however, suggest that common colds induced by RSV may be more prolonged and severe than those induced by other viruses. ${ }^{50}$

\section{Bronchiolitis}

Bronchiolitis is a clinical syndrome. It has been used as a diagnosis since $1940 .{ }^{132}$ It is evident that the diagnostic criteria vary in different centers in the United States and in other countries. ${ }^{133,134}$ The major clinical feature of bronchiolitis that is accepted by all clinicians is expiratory wheezing associated with rhinorrhea and cough. McIntosh ${ }^{135}$ suggested that the term bronchiolitis should be reserved for children under 12 months old. Studies by Mulholland and colleagues ${ }^{136}$ included patients younger than 15 months old and those by Welliver and coworkers ${ }^{137}$ included children younger than 22 months. Henderson and colleagues ${ }^{29}$ defined illnesses with expiratory wheezing of all ages as bronchiolitis, and suggested that the limitation to the first few months of life should be modified. In many European countries a diagnosis of bronchiolitis is given only to severely sick infants, and all of them are treated in the hospi-

TABLE 2

Clinical Findings (\%) of Respiratory Syncytial Virus Infection in 2,903 Hospitalized Patients

\begin{tabular}{|c|c|c|c|c|c|c|}
\hline & $\begin{array}{c}\text { Carlsen } \\
\text { et al }^{124} \\
(1983 ; \\
\mathrm{N}=551 ; \\
\text { Norway) }\end{array}$ & $\begin{array}{c}\text { De Silva and } \\
\text { Hanlon }^{24} \\
(1986 ; \\
\mathrm{N}=768 ; \\
\text { Australia) }\end{array}$ & 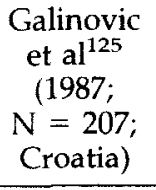 & $\begin{array}{c}\text { Avendano } \\
\text { et al }^{23} \\
(1991 ; \\
\mathrm{N}=239 \\
\text { Chile }) \\
\end{array}$ & $\begin{array}{c}\text { Mufson } \\
\text { et } \mathrm{al}^{126} \\
(1991 ; \\
\mathrm{N}= \\
405 ; \text { USA) }\end{array}$ & $\begin{array}{c}\text { Ruuskanen }^{37} \\
(1992 ; \\
N=733 ; \\
\text { Finland }) \\
\end{array}$ \\
\hline $\begin{array}{l}\text { Upper respiratory tract } \\
\text { infection }\end{array}$ & 8 & 3 & 59 & 4 & 23 & 41 \\
\hline Croup & 1 & 2 & 6 & NS & 11 & 3 \\
\hline Wheezing* & 86 & 71 & 11 & 42 & 27 & 43 \\
\hline Pneumonia & 22 & 3 & 11 & 71 & 39 & 18 \\
\hline
\end{tabular}

"Includes bronchiolitis, wheezy bronchitis, and asthma.

NS $=$ not studied. 
tal. In the Tucson Children's Respiratory Study, ${ }^{22}$ 123 cases of bronchiolitis were diagnosed and only 2 patients needed hospitalization. In another study of 213 infants with bronchiolitis, 123 patients with mild bronchiolitis were discharged from the emergency unit. ${ }^{130}$ Given this variability in the definitions, it is not surprising that the incidence figures vary.

Combining the criteria of several authors, we propose to define bronchiolitis as a syndrome in infants less than 12 months old in whom a first attack of an acute illness, after a brief prodrome of upper respiratory symptoms, is characterized by wheezing, dyspnea, respiratory distress, poor feeding, tachypnea ( $\geq 50 / \mathrm{min}$ ), and radiologic evidence of hyperaeration of the lung. Fine crepitation can usually be heard by auscultation.

Oxygen saturation measured by noninvasive pulse oximetry is the best method for an initial objective assessment and should be performed in all patients with bronchiolitis. ${ }^{130,136}$ Clinical findings may be poor predictors of hypoxemia. ${ }^{138}$ In addition to hypoxemia (oxygen saturation $\leq 90-95 \%$ ), "toxic" appearance (most patients appear well), gestational age of 34 weeks or younger, respiratory rate of $70 /$ min or more, atelectasis on a chest roentgenogram, and age of 3 months or younger have been shown to predict more severe disease. ${ }^{130,136}$ In severe cases, hypercapnia, cyanosis, intercostal and subcostal retractions, and flaring of nasal alae may also develop. Wheezing may not occur in most severe cases, because of decreased air movement. It has been suggested that the respiratory rate is a good guide to re- flect the status of oxygenation. ${ }^{139}$ In contrast, in one recent study, respiratory rate on initial presentation did not predict the severity of bronchiolitis as measured by oximetry. ${ }^{136}$

Chest radiographs show changes in most patients: Hyperaeration, perihilar linear opacities, and bronchial wall thickening have all been described (Figs 4-6). ${ }^{140}$ The pathognomonic finding is hyperaeration, which in the observer variation analysis was also the most reproducible feature of bronchiolitis. ${ }^{141}$ Areas of collapse can also be seen. It has been stated that routine chest radiography brings very little to the treatment of bronchiolitis and chest radiographs should be taken only of patients who need intensive care, who have underlying heart or pulmonary disease, and whose clinical symptoms deteriorate. ${ }^{142}$

In the great majority of patients with RSV bronchiolitis, the symptoms and signs resolve within a few days after admission to a hospital. The duration of hospitalization is usually 2 to 7 days. Infants under 6 weeks old and those with underlying illnesses often need longer hospitalization. ${ }^{143,}{ }^{144}$

Although RSV is the most common etiologic agent of bronchiolitis and virtually the only agent that induces epidemics, other respiratory viruses can also induce bronchiolitis. Welliver and colleagues ${ }^{137}$ described parainfluenza type 1 and 3 virus-induced bronchiolitis, and many studies reported parainfluenza virus as the second most common inducer of bronchiolitis. ${ }^{29,41,136}$ In addition, rhinoviruses, adenoviruses, coronaviruses, and influenza A virus may

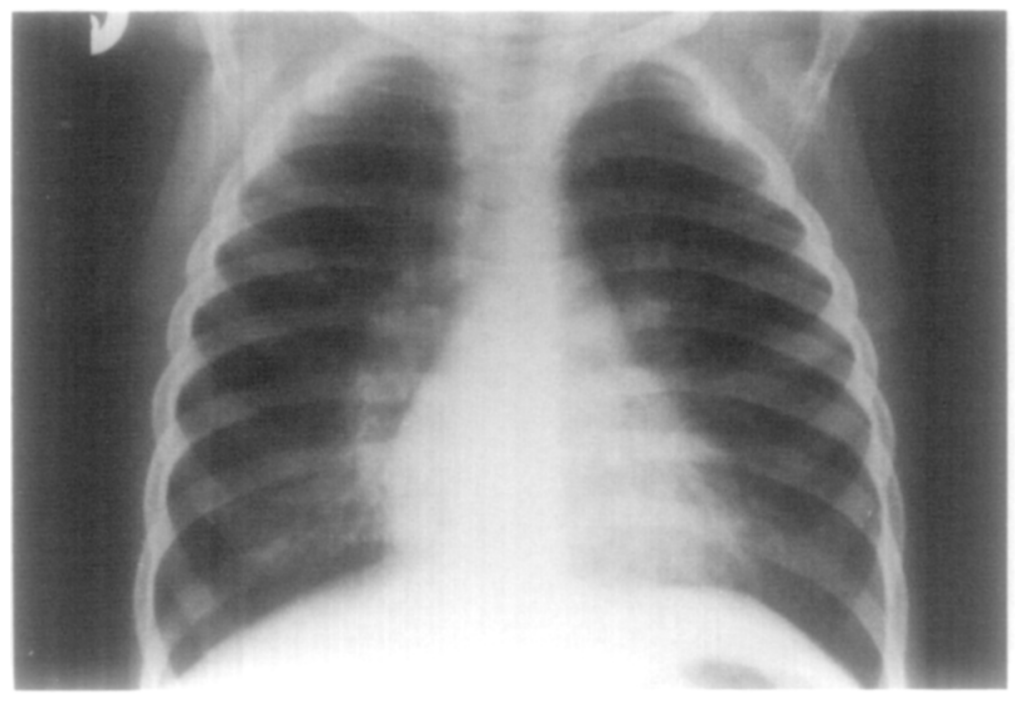

FIGURE 4

Respiratory syncytial virus bronchiolitis in a 12 -month-old infant. Parahilar peribronchial infiltrates with moderate hyperexpansion can be seen. (From Wildin SR, et al: $A m$ J Dis Child 1988; 142:43-46. Copyright 1988, American Medical Association.) 


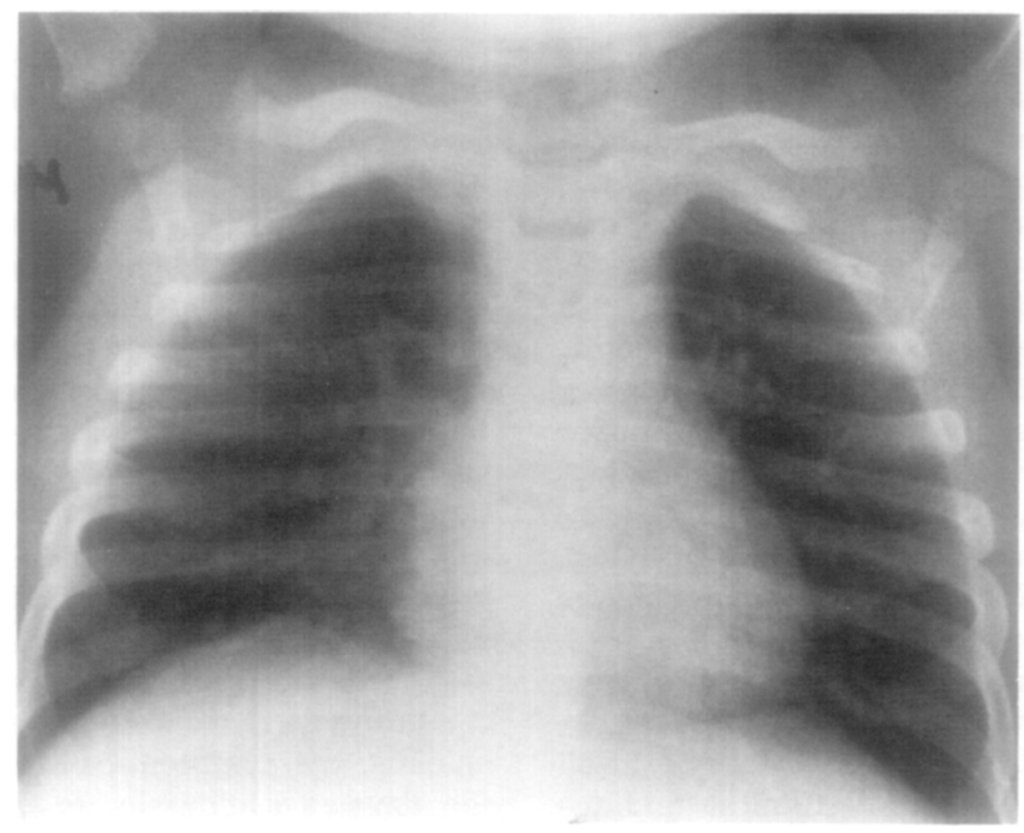

\section{FIGURE 5}

Respiratory syncytial virus pneumonia in a 14-month-old infant. Interstitial infiltrates can be seen in both lungs.

be causative agents of bronchiolitis. ${ }^{29,} 145$ Adenovirus may induce very severe bronchiolitis with high mortality.

Numerous follow-up studies have shown that $22 \%$ to $75 \%$ of the patients with RSV bronchiolitis exhibit recurrent wheezing or pulmonary function abnormalities years later. ${ }^{146}$ The clinical symptoms gradually decrease and disappear usually during the following 10 years. ${ }^{60}$ In some of these patients, the symptoms continue and they can be classified as having asthma. Sly and Hibbert ${ }^{147}$ could diagnose asthma in up to $92 \%$ of 48 patients followed prospectively for 5 years after bronchiolitis. Even after mild bronchiolitis, increased morbidity was docu-

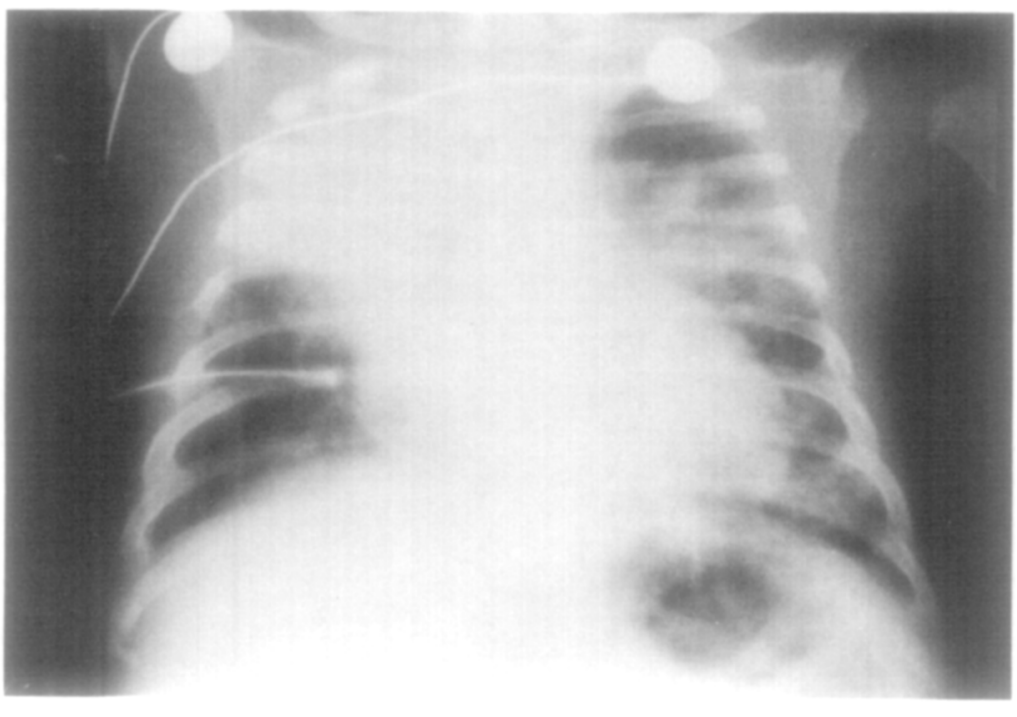

FIGURE 6

Respiratory syncytial virus and pneumococcal pneumonia in a 2-month-old infant. Consolidation of the right upper portion of the lobe and bilateral parahilar peribronchial infiltrates are seen. (From Wildin SR, et al: Am J Dis Child 1988; 142:43-46. Copyright 1988, American Medical Association.) 
mented through the third and fourth year of life, but normal pulmonary function was found between the ages of 8 and 12 years. ${ }^{60}$ In spite of these studies, it is not clear whether RSV can induce long-lasting or even permanent damage to the small airways and in the growing lung. It is possible that development of bronchiolitis may be restricted to subjects already genetically and anatomically at risk for pulmonary hyperreactivity. This possibility is strongly supported by the findings that pre-existing diminished lung function measured very early in life, before any respiratory illness, was found to be a risk factor for recurrent wheezing. ${ }^{58}$ Understanding the possible long-term consequences of RSV bronchiolitis is important because inhaled corticosteroids may be an effective preventive therapy for the development of recurrent wheezy bronchitis and asthma. ${ }^{148-151}$

\section{Wheezy Bronchitis}

Wheezy bronchitis is an acute illness characterized by cough, rhonchi, and expiratory wheezing in young children. ${ }^{152}$ Typically the attacks are recurrent. It has been estimated that $10 \%$ to $20 \%$ of the children wheeze in association with respiratory virus infection. ${ }^{153}$ The most common etiologic agents that induce wheezy bronchitis are RSV, rhinovirus, coronavirus, parainfluenza viruses, adenovirus, and $M y$ coplasma pneumoniae. ${ }^{145,154,155}$ It has been well demonstrated that these microbes may induce hyperreactivity of the airways. ${ }^{156}$ In patients with repeated attacks of wheezing, Mertsola and colleagues ${ }^{145}$ found that wheezing occurred in $58 \%$ of laboratoryconfirmed viral respiratory infections.

It appears that to some extent, bronchiolitis, wheezy bronchitis, and asthma are expressions of the same pathologic process and at present there are no rigid criteria to separate these three illnesses. ${ }^{156}$ A diagnosis of wheezy bronchitis is recommended to be used after the primary attack of expiratory wheezing (bronchiolitis) and in patients having their first attack at an age of more than 11 months. ${ }^{135}$ The clinical picture mimics that of bronchiolitis, although usually wheezy bronchitis is less severe. Expiratory wheezing starts within 24 to 48 hours after the onset of symptoms of respiratory infection and lasts 3 to 7 days. ${ }^{145}$ The majority of children with recurrent wheezy bronchitis stop wheezing after the age of 3 years. ${ }^{155}$ Foucard and Sjoberg ${ }^{157}$ found that $28 \%$ of patients still had attacks of wheezing after 12 years. These patients had more allergic manifestations than patients who stopped wheezing. In older children, wheezy bronchitis cannot be differentiated from virus-induced asthma. At present, it is evident that the use of wheezy bronchitis as a diagnosis varies considerably. ${ }^{158}$

\section{Pneumonia}

It is well established that RSV is the most common, single etiologic agent of childhood pneumonia. RSV infection can be demonstrated in $10 \%$ to $60 \%$ of children with pneumonia (Table 3). In hospitalized patients with RSV infection, pneumonia can be diagnosed in $20 \%$ to $40 \%$ (see Table 2). The variation is due to the different epidemiologic conditions and different diagnostic methods. If a pneumonia study is carried out during an RSV epidemic, the great majority of the cases of pneumonia will be found to be induced by RSV. ${ }^{159}$ The diagnosis of pneumonia should be based on radiographic findings, because it is impossible to differentiate crackles of bronchiolitis and wheezy bronchitis from those found in pneumonia. ${ }^{163}$ Furthermore, often in lobar bacterial-type pneumonia, no crackles can be heard and chest radiograph is the only way to diagnose the illness. ${ }^{34} \mathrm{In}$ addition to virus detection assays, the etiologic tests should include a sensitive IgG serologic assay. In two recent studies, virus culture and sensitive antigen detection assays found only $33(69 \%)$ of 48 cases of RSV-associated pneumonia. ${ }^{33,34}$ It is possible that in pneumonia, the pre-existing symptoms may have lasted long enough that the virus is no longer detectable in the nasopharynx, and sensitive serology may be the only way to detect infection.

The clinical signs and symptoms of RSV pneumonia do not differentiate it from other viral pneumonias. However, usually the epidemiologic situation and the age are highly suggestive. The general condition of the children is good in most cases. Fine crackles heard from both lungs suggest the diagnosis, but they can be also heard in RSV bronchiolitis. Many patients with bronchiolitis also have pneumonia and without a chest radiograph these two illnesses are difficult to differentiate. White blood cell count, erythrocyte sedimentation rate, and serum $\mathrm{C}$-reactive protein levels are within normal limits in most patients. ${ }^{164}$

Rice and Loda ${ }^{163}$ saw in $97 \%$ of the chest radiographs of RSV pneumonia, diffuse interstitial infiltrates that often involved all lobes (see Fig 5). In addition, they frequently recorded hyperinflation and right-upper-lobe consolidation. Interstitial infiltrates were also recorded by Friis and colleagues. ${ }^{165}$ In contrast, Wildin and coworkers ${ }^{140}$ did not find interstitial infiltrates in RSV infection. Instead, they saw parahilar bronchial infiltrates in $92 \%$ and atelectasis in $41 \%$ of the patients (see Figs 4 and 6). Consolidation and alveolar infiltrates have been seen in $10 \%$ to $30 \%$ of patients, ${ }^{141}, 163,166$ but investigators using limited microbiologic diagnostic approaches have been unable to relate these findings to possible bacterial co-infection. ${ }^{165}$ In general, a reliable compari- 
Respiratory Viruses (\%) Associated With Childhood Pneumonia

\begin{tabular}{|c|c|c|c|c|c|}
\hline & $\begin{array}{c}\text { Paisley et al }^{159} \\
(1984 ; \\
N=102 ; \\
\text { USA })\end{array}$ & $\begin{array}{c}\text { Turner et al }^{160} \\
(1987 \\
\text { N=98; } \\
\text { USA })\end{array}$ & $\begin{array}{c}\text { Isaacs }^{161} \\
\quad(1989 ; \\
\text { N = 57; } \\
\text { England })\end{array}$ & $\begin{array}{c}\text { Claesson et al }{ }^{162} \\
(1989 ; \\
N=336 ; \\
\text { Sweden })\end{array}$ & $\begin{array}{c}\text { Ruuskanen et al }{ }^{34} \\
(1992 ; \\
N=50 ; \\
\text { Finland) }\end{array}$ \\
\hline $\begin{array}{l}\text { Respiratory syncytial } \\
\text { virus }\end{array}$ & 60 & 28 & 11 & 20 & 30 \\
\hline Rhinovirus & 6 & 2 & 9 & NS & 10 \\
\hline Parainfluenza & 4 & 5 & 4 & 3 & 8 \\
\hline Adenovirus & 1 & 1 & 7 & 3 & 10 \\
\hline Influenza $A$ & 1 & 2 & 0 & 3 & 2 \\
\hline
\end{tabular}

NS $=$ not studied.

son of different radiologic findings in RSV infection is difficult, because the descriptive terms vary widely.

\section{Infection in Newborn}

Although RSV infection is rare in the first 4 weeks of life, epidemics in neonates have been described. Hall and coauthors ${ }^{127}$ reported RSV infection in $28 \%$ of 82 babies studied in a neonatal unit and in $35 \%$ of those hospitalized for 6 days or longer. Sixty-one percent of the babies had respiratory illness, and of these, approximately half had upper respiratory tract infection and the other half, pneumonia. Pneumonia was diagnosed more often in infants over 3 weeks old. When pneumonia during the first month of life was studied, RSV was found to make $55 \%$ of all isolates in the 40 patients studied. ${ }^{167}$ It is important to note that in many infants, the RSV infection may be atypical; that is, the major manifestations are apnea, lethargy, irritability, and poor feeding. Interestingly, in two neonates with RSV infection who were described, fever, thrombocytopenia, and rash covering the trunk were the major clinical symptoms. ${ }^{168}$ These observations suggest that RSV should be included in the sepsis workup of infants during RSV season. ${ }^{169}$

Apnea (defined as a cessation of breathing for more than 15 seconds or associated with cyanosis or bradycardia) $^{170}$ is a well-documented symptom of RSV infection. It occurs in $20 \%$ to $25 \%$ of young infants. ${ }^{127,170,171}$ The mechanisms of RSV-associated apnea are not well understood. Anas and colleagues $^{170}$ found apnea to be diaphragmatic or nonobstructive; that is, a respiratory effort was absent. In a study on 58 apnea spells in two infants, two types of apnea were found. ${ }^{172}$ Nonperiodic prolonged apnea was associated with swallows, coughing, obstructed breaths, and central apnea. Mimicking apnea of prematurity, these spells were mixed or obstructive. The other patients with apnea had a regularly recurrent pattern and the apneic spell started with a cessation of airflow in late inspiration or early expiration. A recent study ${ }^{173}$ in lambs suggests that RSV infection may alter the sensitivity of the laryngeal chemoreceptors locally. Stimulation of these receptors could result in prolonged apnea.

RSV-associated apneic spells are more common in premature babies and young infants, especially in those who have had apnea during the newborn period. Apneic spells usually last only a few days but may be severe enough to require ventilatory support, so infants who develop apnea should be initially hospitalized for cardiorespiratory monitoring. ${ }^{170}$ After hospitalization, home respiratory monitoring is not recommended unless the infant has had pre-existing apnea or has neurologic abnormalities. ${ }^{171}$ When 48 infants with RSV-associated apnea were followed for the first year of life, Church and colleagues $^{171}$ found that the patients were not at risk of subsequent apnea; however, one otherwise healthy infant died at the age of 4 months of aspiration pneumonia.

\section{Infection in Adults}

It is now well-documented that RSV infection occurs commonly in adults as well as children. In a family study, $17 \%$ of the adults living with infected children also became infected. ${ }^{50}$ In adults, RSV infection can be asymptomatic or can induce mild to moderate upper respiratory tract symptoms. In healthy adults, the infection is rarely severe or fatal. ${ }^{174}$ The symptoms include fever for 1 to 4 days, nasal congestion, rhinorrhea, sore throat, ear pain, and cough lasting 10 days or longer. The average duration of virus shedding is 5 days. ${ }^{74}$ Based on clinical features, RSV infection cannot be differentiated from common cold induced by other etiologic agents. Adults who are immunocompromised, institutionalized, or aged or who have some underlying illness (especially pulmonary disease) may be at risk of severe RSV pneu- 
monia. The occurrence of pneumonia in long-term care facilities varies from $5 \%$ to $67 \%$, with mortality from 0 to $53 \% .^{28}$ The chest radiograph usually reveals patchy changes, diffuse consolidation, or interstitial infiltrates. Recently, Guidry and coauthors ${ }^{175}$ reported RSV infection in 5 of 11 intubated patients in a medical intensive care unit. Two patients died. Several dual viral infections were recognized, although none of the patients was receiving significant immunosuppressive therapy. In addition, 4 of 48 ward patients became infected. One physician had the virus isolated from his respiratory secretions, a finding which agrees with the hypothesis that hospital personnel usually introduce the illness to the ward. During outbreaks, RSV must be included in the differential diagnosis of fever with evidence of pulmonary infiltrates in immunocompromised adults. ${ }^{176-178}$ In one study, 3 of 9 immunocompromised adult patients with RSV infection died. ${ }^{177}$ Bronchoalveolar lavage and rapid tests are thus recommended for the diagnosis. ${ }^{178}$ Ribavirin may be beneficial in the treatment of severe infections in adults. ${ }^{174}$

\section{High-Risk Children}

Children at increased risk from RSV infection include young infants with prematurity, ${ }^{127,179}$ bronchopulmonary dysplasia, ${ }^{180}$ congenital heart disease, ${ }^{181}$ congenital or acquired immunodeficiency, ${ }^{89},{ }^{182-184}$ and cystic fibrosis. ${ }^{185}$ Premature infants are more likely to have apneic spells, atelectasis/infiltrates, and hyperinflation as seen on the chest radiograph, and may require oxygen therapy and mechanical ventilation. Consequently, these patients need longer hospitalization. ${ }^{179}$ Two studies suggested that intubation increases the risk for fatal illness. ${ }^{122,175}$ RSV infection is a major reason for rehospitalization of children with bronchopulmonary dysplasia. In these patients, large numbers of siblings and parental smoking are risk factors, as well as recent need for home oxygen therapy. ${ }^{180}$

Clinicians have been long aware that RSV infection may be particularly severe, long lasting, and fatal in children with congenital immunodeficiency diseases. Although all such patients whom we are aware of have had both T- and B-cell defects, animal studies suggested that $T$ cell-mediated cellular immunity is responsible for terminating RSV infection. ${ }^{96}$ No reports of possible increased severity of RSV infection in children with hypogammaglobulinemia have been published. Increased morbidity and mortality have, however, been documented in children undergoing chemotherapy. ${ }^{183} \mathrm{Pohl}$ and associates ${ }^{184}$ reported RSV infection in 17 children who underwent liver transplantation. The clinical symp- toms were similar to those in healthy children. Two patients died. The risk factors appeared to be acquisition of infection soon after transplantation and preexisting lung disease. Recently, RSV infection was studied in 10 human immunodeficiency virus (HIV)-infected children who experienced pneumonia and prolonged viral carriage. Two children died, both with concomitant bacterial superinfection. ${ }^{186}$

Congenital heart disease is another wellestablished risk factor for severe RSV infection. Cardiac function is not depressed in patients with normal hearts who have RSV infection. ${ }^{187}$ However, Sreeram and coworkers ${ }^{188}$ found tricuspid valve regurgitation in 11 of 21 children with bronchiolitis. MacDonald and associates ${ }^{181}$ reported that infants with heart disease and RSV infection needed more treatment in the intensive care unit and more ventilator therapy than those without congenital heart disease. The mortality in infants with heart disease was $37 \%$ versus $1.5 \%$ in control patients. Even higher mortality $(73 \%)$ was recorded in patients with pulmonary hypertension. In our experience, these mortality numbers are exceptionally high and probably should not be generalized.

\section{Group $A$ and $B$ Infections}

At present it is not clear whether group A and B RSV infections are clinically different. McConnochie and colleagues ${ }^{189}$ reported that group $\mathrm{A}$ infections were more severe, requiring more mechanical ventilation and producing higher carbon dioxide tension. Furthermore, in a study on 1,209 hospitalized children, those with group A RSV infections more often required intensive care. ${ }^{190}$ These observations are in agreement with those from Huntington (West Virginia) ${ }^{126}$ England, ${ }^{191}$ Argentina, ${ }^{192}$ and Uruguay. ${ }^{193}$ In contrast, studies in Tecumseh, ${ }^{43}$ Boston, ${ }^{194}$ Cleveland, ${ }^{195}$ and Japan ${ }^{196}$ found no differences in the severity of disease relative to group A or B RSV infections.

\section{Secondary Bacterial Infections}

Acute otitis media is the most common bacterial complication of RSV infection. ${ }^{197}$ Epidemiologic surveillance data show a strong association between RSV infections and acute otitis media. Markedly increased rates of acute otitis media have been recorded during RSV epidemics. About 50\% of hospitalized children with RSV infection have or subsequently develop acute otitis media. ${ }^{198}$ RSV is the most common virus isolated from the middle-ear fluid, accounting for $41 \%$ of 96 virus isolates reported. ${ }^{197}$ Although RSV has betil frequently founu' in the middle-ear fluid, there is at present no direct proof that RSV replicates in middle-ear epithelial 
cells. Most patients with RSV-associated acute otitis media also have a bacterium in the middle ear. ${ }^{199}$ Concomitant RSV infection may explain the poor response to antibiotic therapy in acute otitis media. ${ }^{200-202}$

Systemic bacterial complications of RSV infections are rare in developed countries. The great majority of children with RSV infection have normal values for white blood cell count, erythrocyte sedimentation rate, and serum C-reactive protein concentration. ${ }^{164}$ Hall and coworkers ${ }^{203}$ observed subsequent confirmed systemic bacterial infections in only 2 of 352 children who had not received previous antibiotic therapy. These children had blood culture-positive streptococcal pneumonia and bronchopulmonary dysplasia. The risk of secondary bacterial infection was markedly increased $(11 \%)$ in patients who had at least 5 days of parenteral antibiotics. Timmons and coworkers ${ }^{204}$ studied retrospectively the charts of 108 children with RSV infection and found 3 with blood cultures positive for Streptococcus pneumoniae. Tristram and colleagues ${ }^{205}$ reported 4 blood culture-positive $S$. pneumoniae infections in 189 children with RSV infection. Furthermore, 4 adenovirus infections, 1 cytomegalovirus infection, and 1 Pneumocystis carinii infection were detected simultaneously with RSV. In addition to these clinical studies, the few autopsy studies that have been reported to date do not support a significant role of concomitant bacterial infections with RSV. ${ }^{119,} 120$ These figures probably underestimate the true occurrence of secondary bacterial infections, since blood culture is infrequently positive in childhood pneumonia. Nonetheless, antibiotics have not been shown to be beneficial in the treatment of RSV infections. ${ }^{206,}{ }^{207}$ In a developing country, RSV infection may often be complicated by systemic bacterial infection. In a study of Ghafoor and coworkers ${ }^{208}$ in Pakistan, S. pneumoniae and Hemophilus influenzae were isolated from the blood of $26 \%$ of 491 children with RSV infection.

Simultaneous infections with RSV and Bordetella pertussis have been demonstrated. In one study, ${ }^{209}$ of 29 children with pertussis, 14 also had RSV infection. The temporal sequence of these two infections could not be determined. The symptoms and signs of RSV infection or pertussis alone were similar, as were white blood cell and lymphocyte counts. It is possible that RSV may make young infants more susceptible to pertussis.

A series of recent studies suggested that $30 \%$ to $40 \%$ of children with RSV infection have concomitant bacterial infection. ${ }^{33,34,210,}{ }^{211}$ In all these studies, indirect measures of bacterial infection were used: pneumococcal antigen detection from serum and urine, and measurement of antibody conversion in serum for $S$. pneumoniae, nontypable $H$. influenzae, and Moraxella catarrhalis. Further studies are needed to verify the clinical value of these measures of bacterial infections.

\section{Nosocomial Infections}

RSV spreads readily among hospitalized populations. Hospital personnel are the leading cause of nosocomial respiratory infection in young children and adults. ${ }^{212-214}$ Several epidemics in nurseries, intensive care units, hospital wards, and long-term care facilities have been described. New data show that RSV nosocomial transmission may be more complex than was once believed. Several antigenically different RSV subgroups have been demonstrated during a single hospital epidemic, suggesting that the infection was transmitted from several sources. ${ }^{179}$

Several measures have been found helpful and effective in preventing RSV nosocomial infections. The use of rapid diagnostic techniques permits the detection of infection within hours after the admission. The RSV-infected child should be placed in a single room, if possible. Alternatively, both the patients and staff should be cohorted and careful handwashing protocols observed (Fig 7). ${ }^{215,} 216$ RSV is very sensitive to alcohol and detergents because it has a lipid membrane that is destroyed in less than 60 seconds. ${ }^{217}$ Recommendations about the use of gowns and masks vary. Hall and Douglas ${ }^{218}$ and Murphy and colleagues ${ }^{219}$ were unable to show any beneficial effects for their use. In contrast, LeClair and associates ${ }^{220}$ found that the use of gowns and gloves substantially reduced the nosocomial transmission of RSV infection, after specific intervention to monitor compliance was carried out by the nursing staff. In addition to these procedures, use of goggles covering the eyes and nose ${ }^{128}$ and limiting visitors (no siblings, no visitors with respiratory symptoms except parents wearing a mask $)^{221}$ have been demonstrated to reduce the transmission of RSV in hospital settings.

\section{Mortality}

The mortality associated with primary RSV infection in otherwise healthy children is estimated to be $0.005 \%$ to $0.020 \% .{ }^{222}$ In hospitalized children, mortality rates are estimated to be from $1 \%$ to $3 \% .^{2}$ Considerably higher mortality rates in children with cardiopulmonary abnormalities and in immunosuppressed subjects (see High-Risk Children) have been suggested.

Due to the common occurrence of RSV infection, even a low mortality rate may have marked impact 


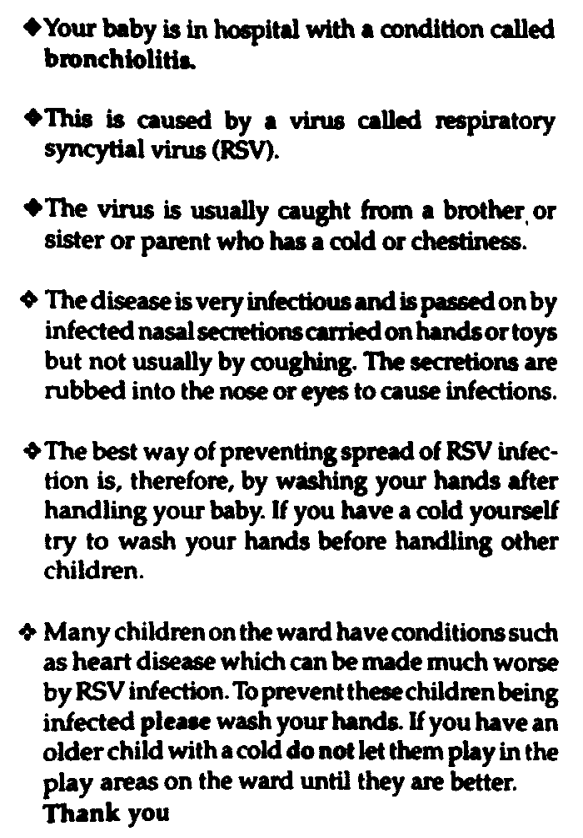

- Your baby is in hospital with a condition called

This is caused by a virus called respiratory

The virus is usually caught from a brother, or sister or parent who has a cold or chestiness. (a) but not usually by coughing. The secretions are

The best way of preventing spread of RSV infecis, therefore, by washing your hands after handling your baby. If you have a cold yourself try to wash your hands before handling other as heart disease which can be made much worse older child with a cold do not let them play in the Thank you

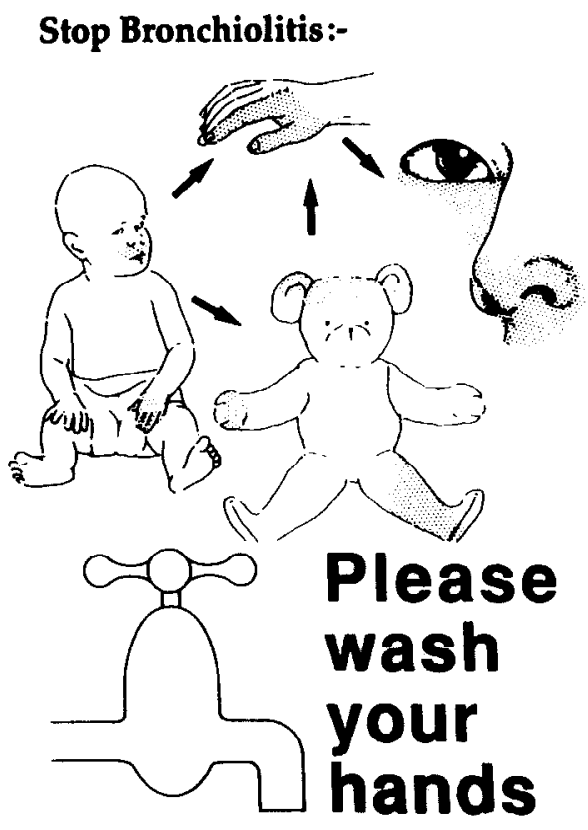

FIGURE 7

Information leaflet given to parents. (From Isaacs D, et al: Arch Dis Child 1991; 66:227-231. Used by permission.)

on the total mortality of young children. Anderson and colleagues ${ }^{39}$ compared the temporal patterns of respiratory viral isolations from ten laboratories in the United States with that of deaths of children. They found that RSV isolations were clearly associated with the respiratory deaths of children 1 to 11 months old. Influenza virus infection was associated with the deaths of children 24 to 59 months old. The investigators estimated that between 90 and 1,900 deaths of children less than 1 year old may be associated with RSV each year.

A significant correlation has been shown to exist between the occurrence of sudden infant death syndrome (SIDS) and RSV infections. ${ }^{39,}{ }^{223}$ RSV has been demonstrated in the lungs of up to $25 \%$ of infants who died from SIDS. ${ }^{224}$ Prolonged apnea, which is a major sign of newborn RSV infection, may explain some of these deaths. At present, however, the role of RSV in SIDS is not fully understood.

\section{Immune Response}

RSV infection induces both serum and mucosal IgM, $\operatorname{IgA}, \operatorname{IgG}$, and IgE antibodies. Primary RSV infection induces IgM response in 5 to 10 days, depending on the age of the patient. Meurman and colleagues ${ }^{225}$ found an IgM response in $73 \%$ of the 26 patients with RSV infection, including $63 \%$ of the infants less than 6 months old, and $100 \%$ of the patients 1 to 2 years old. Welliver and associates ${ }^{226}$ also found a lower IgM response in patients less than 6 months old. IgM antibodies persist, usually, for 1 to 3 months. However, Popow-Kraupp and coworkers ${ }^{227}$ found IgM antibodies against RSV to remain detectable at least 1 year, using immunoblot analysis.

RSV-specific IgG antibody response can be detected in most patients; it reaches maximum values in 20 to 30 days after the onset of symptoms. ${ }^{225,226}$ Again, lower responses in young infants have been reported. ${ }^{228}$ IgG response occurs mainly in IgG1 and IgG3 subclasses, indicating the antigenic nature of the protein moieties of the $F$ and $G$ proteins of RSV. ${ }^{229}$ One year after the primary infection occurs, RSV-specific IgG levels appear to decline to low levels. After re-infection, a booster effect is noted, with high titers of IgG detectable within 5 to 7 days. ${ }^{226}$

The serum IgA response to RSV infection occurs several days later than IgM and IgG responses. ${ }^{225}$ Interestingly, Meddens and coworkers ${ }^{228}$ found an IgA response most often in the younger age group, suggesting that it may have diagnostic value. IgA can be found free and cell bound in nasopharyngeal secretions of patients with RSV infections. Free antiRSV IgA appears within 2 to 5 days after infection and peak titers are obtained between 8 and 13 days. ${ }^{80}$ The nasopharyngeal IgA response is greater in children older than 6 months. Furthermore, nasal secretions contain free RSV-specific IgM, IgG, and IgE and cell-bound IgM, IgG, and IgE during RSV 
infection. ${ }^{80} \mathrm{~A}$ mucosal immune response to RSV has also been demonstrated by RSV-induced antibody response in vitro in tonsillar lymphocytes. ${ }^{230}$

Several studies have demonstrated specific antibody responses to major RSV structural proteins. ${ }^{45,} 231-233$ Hendry and coworkers ${ }^{232}$ showed that the antibody responses to the F protein of RSV were cross-reactive with both RSV strains tested, whereas antibody responses to the $G$ protein were subgroup specific. Similar findings were reported by Muelenaer and coauthors, ${ }^{45}$ who studied group-specific antibody responses to primary and secondary RSV infections. These observations suggest that primary and secondary infection with group A viruses can induce cross-reactive neutralizing antibody responses to group $B$ viruses.

Siber and coworkers ${ }^{79}$ recently studied different RSV antibody assays to detect IgG with high virusneutralizing and animal protective activity. Results of direct ELISAs using purified $F$ protein, $G$ protein, or RSV-infected cell lysate, two competitive ELISAs with RSV-neutralizing antibodies to F2 or F3 epitopes of $F$ protein, plaque reduction neutralization assays, and microneutralization assays were compared. Interestingly, they found a low level of correlation between the assays, suggesting that each assay may measure functionally different populations of RSV antibodies.

RSV infection induces specific cell-mediated immune responses including lymphocyte transformation, cytotoxic $\mathrm{T}$-cell response, and antibodydependent cellular cytotoxicity response. These are discussed in the section Pathogenesis.

\section{Diagnosis}

During an outbreak, diagnosis of RSV infection can often be assumed on the basis of the signs and symptoms of infection and the age of the patient. Specific viral diagnosis is necessary for the cohorting of hospitalized patients, in severely ill patients needing intensive care, and in high-risk patients. Specific diagnosis also is indicated if a patient is being considered for antiviral chemotherapy or has failed antibiotic therapy.

$\Lambda$ properly collected and transported mucus sample from the nasopharynx is crucial in the diagnosis of RSV infection. It has been shown that recovery of the virus is highly dependent on the training and interest of the personnel collecting the samples. ${ }^{234}$ Nasopharyngeal specimens can be obtained by swabbing, washing, or aspiration. Although still in common use, nasopharyngeal and pharyngeal swabs give the worst results. ${ }^{235}$ Nasal wash and nasopharyngeal aspiration are both recommended as the methods of choice. ${ }^{2,44}$ In nasal washing, 3 to 7 $\mathrm{mL}$ of phosphate-buffered saline solution in a rubber bulb is squeezed into the nostril and then recollected by releasing the bulb. Almost all the saline solution instilled can be recovered. ${ }^{2}$ Nasopharyngeal aspiration specimens are collected by a disposable catheter and mucus extractor (e.g., Vygon, Ecouen, France) connected to a mechanical vacuum. Alternatively, a no. 5 French nasogastric feeding tube connected to a syringe has been used for aspiration. ${ }^{236}$ The catheter is transported through a nostril into the nasopharynx until it reaches the backwall. After the vacuumer is activated, the catheter is slowly drawn out, aspirating the secretions. The volume of the specimen collected is usually 0.5 to $2.0 \mathrm{~mL}$. Samples for virus culture should be placed in the proper transfer medium and kept on ice until processed. The clinical specimens should be collected as early as possible after the onset of symptoms. The recovery of the virus decreases markedly after 5 to 7 days. In two studies, in only about $50 \%$ of the cases of documented RSV could RSV still be detected after the symptoms had lasted longer than 7 days. ${ }^{35,} 237$

During the last 5 to 6 years, an avalanche of studies on different RSV diagnostic methods have been reported. The different laboratory techniques are thoroughly discussed in several recent reviews. ${ }^{3,4,235}$ RSV infection is usually diagnosed by detecting the virus by tissue culture infectivity or by demonstrating viral antigen by immunoassay in the nasopharynx. After the acute phase of the illness, the diagnosis can be made by demonstrating a significant increase of specific antibodies in paired serum samples. In addition, nucleic acid detection and polymerase chain reaction methods have been described, but they are currently available only in certain research laboratories. ${ }^{95,238-240}$

Rapid detection of viral antigen by immunoassay is at present the most suitable single method to demonstrate RSV infection. Several commercial kits for ELISAs or membrane enzyme immunoassays have been developed. For the ELISA procedure, a polystyrene microtiter well, a bead, or a nitrocellulose membrane is coated with anti-RSV antibody. The antigen in the clinical sample is captured by the antibody and this complex is captured by a second specific antibody, which is labeled (direct assay) or followed by a labeled anti-species antibody against the second one (direct assay). Peroxidase and alkaline phosphatase are most commonly used as labels. The assay time is 2 to 5 hours. Two membrane enzyme assays do not require any special equipment and take only 15 to 20 minutes. The sensitivity and specificity of ELISAs and membrane immunoassays range usually from $80 \%$ to $90 \%$ (Table 4 ). ${ }^{241-250}$ The 
TABLE 4

Rapid Detection of Respiratory Syncytial Virus Antigen in Nasopharyngeal Specimens Compared to Viral Culture (Studies From 1988 to 1991)

\begin{tabular}{|c|c|c|c|c|}
\hline Commercial Test $^{*}$ & Reference & $\begin{array}{c}\text { No. of Positive } \\
\text { Cultures }\end{array}$ & Sensitivity (\%) & Specificity (\%) \\
\hline \multirow[t]{4}{*}{ Kallestad EIA (75 min) } & Johnson and Siegel ${ }^{241}$ & 133 & 87 & 88 \\
\hline & VanBeers et $\mathrm{al}^{242}$ & 124 & 74 & 76 \\
\hline & Wren et $\mathrm{al}^{243}$ & 93 & 76 & 90 \\
\hline & $\begin{array}{l}\text { Ahluwalia and } \\
\text { Hammond }^{244}\end{array}$ & 61 & 79 & 98 \\
\hline \multirow[t]{3}{*}{ Ortho EIA $(5 \mathrm{hr})$} & Thomas and Book 245 & 26 & 88 & 87 \\
\hline & $\begin{array}{l}\text { Ahluwalia and } \\
\text { Hammond }\end{array}$ & 61 & 95 & 99 \\
\hline & $\begin{array}{l}\text { Christensen and } \\
\text { Flanders }\end{array}$ & 22 & 86 & 78 \\
\hline \multirow[t]{4}{*}{ Directigen (15 min) } & Freymuth et $\mathrm{al}^{247}$ & 103 & 91 & 98 \\
\hline & VanBeers et $\mathrm{al}^{242}$ & 124 & 88 & 76 \\
\hline & Rothbarth et $\mathrm{al}^{248}$ & 38 & 76 & 73 \\
\hline & Halstead et $\mathrm{al}^{249}$ & 57 & 76 & 80 \\
\hline \multirow[t]{5}{*}{ TestPack (20 min) } & Thomas and Book ${ }^{245}$ & 55 & 91 & 95 \\
\hline & Rothbarth et $\mathrm{al}^{248}$ & 38 & 92 & 97 \\
\hline & Wren et $\mathrm{al}^{243}$ & 93 & 92 & 91 \\
\hline & Halstead et $\mathrm{al}^{249}$ & 57 & 94 & 100 \\
\hline & Swierkosz et al $^{250}$ & 70 & 100 & 95 \\
\hline
\end{tabular}

*In parentheses are the times required to perform the tests.

$\mathrm{EIA}=$ enzyme immunoassay.

tests are simple and inexpensive and do not require a highly experienced technician. Furthermore, the nasopharyngeal samples can be sent by mail or kept overnight in a refrigerator. The tests measure free antigen, so the samples do not need to have intact epithelial cells. Monoclonal antibodies for ELISA are also available for influenza $A$ and $B$ viruses; parainfluenza type 1,2, and 3 viruses; and adenovirus. Currently, the most sensitive antigen detection method is time-resolved fluoroimmunoassay (TR-FIA), which requires only 1 hour of incubation and is also available for several other viruses. ${ }^{35,44}$

If the number of samples per day is limited, direct or indirect immunofluorescent tests may be an alternative for ELISA. They have comparable sensitivity and specificity and monoclonal antibody reagents are available commercially. ${ }^{235}$ As much as $25 \%$ of the nasopharyngeal samples may, however, be inadequate for immunofluorescence studies due to the lack of intact cells. ${ }^{235}$ Furthermore, special ultraviolet light microscope and well-trained microscopists are needed.

Although rapid antigen detection tests are now recommended as a primary test to detect RSV infection, detection of infectious virus by cell culture still remains the standard procedure. Optimally, the procedure is performed on several cell lines at the same time. Most often Hep-2, HeLa and Vero cells are used. The susceptibility of cell lines to RSV must be monitored. The typical cytopathic effect is usually seen in 2 to 7 days, but may take as long as 21 days. ${ }^{235,246}$ The cell culture infectivity is markedly improved by the shell vial technique: a procedure involving short centrifugation of the sample and detection of virus antigen by peroxidase staining ${ }^{251}$ or immunofluorescence ${ }^{236}$ after 16 to 48 hours of culture. In addition to the short assay time, the sensitivity is increased.

The cell culture assay is necessary because it also will detect other, often unexpected viruses; furthermore, some species (e.g., rhinoviruses) cannot at present be detected by antigen tests. Several other viruses may occur in the community concomitantly with an RSV epidemic. Furthermore, some specimens may show positivity in cell culture and negativity in antigen detection tests and vice versa. ${ }^{235}$ The disadvantages of cell culture are that the cultures are difficult to maintain, samples need rapid processing, identification needs skill and experience, and the results may come too late to affect the decision-making process to patient management.

Serologic tests provide immunologic evidence of infection after the acute phase of the disease. They are especially necessary in clinical research, when the etiologies of different infections are studied. Several studies have shown the complement fixation test to be insensitive, especially in very young children. ${ }^{3,4}$ It has been replaced by more sensitive assays of IgG-specific antibodies measured by enzyme immunoassay. ${ }^{237}$ 


\section{Treatment}

\section{Supportive Care}

Many hospitalized patients with RSV infection are hypoxemic. Although respiration and heart rates are routinely monitored, they may be unreliable predictors of hypoxemia. Pulse oximetry is recommended for all young infants with RSV-induced lower respiratory tract infection. ${ }^{130,136}$ Patients having oxygen saturations lower than $95 \%$ usually require hospitalization. ${ }^{252}$ Supplemental humidified oxygen therapy is the cornerstone of the treatment. The majority of patients respond well to $40 \%$ oxygen. Continuous monitoring of blood gases is necessary. Acute respiratory acidosis ( $\mathrm{pH}<7.25$, arterial carbon dioxide pressure $\left[\mathrm{PaCO}_{2}\right]>60 \mathrm{~mm} \mathrm{Hg}$ ), severe hypoxemia (arterial oxygen pressure $\left[\mathrm{PaO}_{2}\right]<60 \mathrm{~mm} \mathrm{Hg}$ in $40 \%$ oxygen) that is unresponsive to oxygen administration, and recurrent prolonged apnea are indications that ventilatory support therapy may be required. ${ }^{253-256}$ The mean duration of mechanical ventilation has been reported to be 4 to 9 days. ${ }^{254},{ }^{255}$ Mechanical ventilation should be discontinued when the patient is able to maintain a $\mathrm{PaO}_{2}$ of at least $70 \mathrm{~mm} \mathrm{Hg}$ and $\mathrm{PaCO}_{2}$ of at least $45 \mathrm{~mm}$ $\mathrm{Hg}$. Supplemental oxygen is recommended as long as oxygen saturation is lower than $95 \%{ }^{256}$ Extracorporeal membrane oxygenation has been successfully used when maximal ventilatory support has failed to maintain adequate ventilation. ${ }^{257}$

Intravenous hydration has also been recommended. However, two recent studies reported markedly elevated plasma antidiuretic hormone (ADH) levels in children with bronchiolitis. ${ }^{258,259}$ Hypertranslucency on chest radiograph, hypercapnia, and mechanical ventilation are associated with elevated plasma ADH levels. The authors of these studies stressed that in spite of normal serum sodium levels, the patient may be overloaded with fluids. Careful monitoring of body weight in addition to plasma electrolyte concentrations is thus necessary, and in some cases, restricted fluid intake may be indicated.

Mist treatment and physiotherapy were once standard supportive therapies for bronchiolitis. At present there is evidence that they may do more harm than good. ${ }^{260}$ Frequent aspiration of excessive nasopharyngeal mucus may be necessary in some patients to relieve breathing and feeding difficulties.

\section{Bronchodilator Drugs}

The use of bronchodilators in the treatment of bronchiolitis and wheezy bronchitis in young infants has been controversial. Earlier studies have suggested little or no beneficial effects of isoprenaline, epinephrine, salbutamol (albuterol), or theoph- ylline. ${ }^{260-263}$ Several recent studies, however, suggested that bronchodilators may have a beneficial effect in some patients with bronchiolitis. Subcutaneous epinephrine was found effective in the treatment of wheezing in $63 \%$ of patients less than 12 months old and in $92 \%$ of those 12 to 24 months old when respiratory rate, wheezing, and retractions were used as clinical criteria. ${ }^{264}$ Mallory and associate $^{265}$ studied 14 mechanically ventilated infants with RSV bronchiolitis. They showed that isoetharine or isoproterenol aerosols significantly increased the maximum expiratory flow rate at $25 \%$ $\left(\mathrm{MEF}_{25}\right)$ of forced vital capacity (FVC). Schuh and colleagues $^{266}$ demonstrated significant improvements in the accessory muscle score, respiratory rate, and oxygen saturation after two doses of nebulized salbutamol in 40 infants with bronchiolitis. A positive response to such therapy was also shown by children less than 6 months old. In a doubleblind, placebo-controlled study Klassen and cowork$\mathrm{ers}^{267}$ found improvement in clinical scores but not in oxygen saturation. Significant improvement in lung function was observed in wheezy infants after 15 minutes of inhalation of salbutamol compared to placebo. ${ }^{268}$ Studying respirosonography in infants with bronchiolitis, Tal and coworkers ${ }^{269}$ showed that nebulized salbutamol induced a marked decrease in the duration of expiratory wheezing in 7 of 16 infants studied. Recently, nebulized metaproterenol was demonstrated to be effective in $40 \%$ of those aged 12 months and younger and in $52 \%$ of those 24 months and older with acute wheezing. ${ }^{270}$ These findings suggest that nebulized bronchodilator therapy should be tested in children with bronchiolitis. However, the response should be carefully monitored, because in some patients salbutamol may induce a fall in oxygen saturation. ${ }^{262,263}$ High doses of nebulized salbutamol $(0.15 \mathrm{mg} / \mathrm{kg})$ may be needed, as shown in older children with asthma. ${ }^{271}$

\section{Corticosteroids}

Five earlier studies on the use of systemic corticosteroids in the treatment of acute bronchiolitis showed no beneficial effects. ${ }^{261,272}$ In a report in 1970, the American Academy of Pediatrics concluded that "there is no scientific basis for the routine administration of corticosteroids in bronchiolitis. ${ }^{273}$ This conclusion is still valid today. Recently, there has been a resurgence in studies of corticosteroids in bronchiolitis. Tal and coworkers ${ }^{274}$ showed in a small number of patients that intramuscular dexamethasone and salbutamol used together, but not separately, had favorable effects on the clinical course of children with acute wheezing associated with upper respiratory tract symptoms. However, 
these findings could not be confirmed by Springer and coworkers, ${ }^{272}$ who studied only patients with the first attack of bronchiolitis.

Inhaled steroids are now the main treatment of childhood asthma. Carlsen and colleagues ${ }^{148}$ showed that nebulized beclomethasone for 8 weeks markedly decreased the recurrent severe wheezing attacks after bronchiolitis. Furthermore, Bisgaard and associates $^{149}$ demonstrated that budesonide inhaled for 12 weeks from a pressurized aerosol through a spacer with a face mask significantly reduced the frequency of recurrent wheezing in children 11 to 36 months old. Recently, Noble and coworkers ${ }^{151}$ confirmed the beneficial effects of inhaled budesonide in children under 18 months old with chronic wheezing. In Europe, inhaled steroids are already a standard treatment for recurrent wheezing after bronchiolitis, but further studies are needed to establish the dosage, duration, and method of delivery as well as possible long-term adverse effects.

\section{Ribavirin}

Ribavirin (1- $\beta$-D-ribofuranosyl-1,2,4-triazole-3-carboxamine) is an analog of guanosine and inosine. It has a broad antiviral spectrum, and is effective not only against RSV, but also in vitro against measles, parainfluenza, and influenza viruses. ${ }^{275}$

The drug is delivered as an aerosol by a special mist generator for 18 to 20 hours daily for 3 to 5 days. Recently, high-dose, short-duration therapy has been studied with promising results. ${ }^{276}$ Given orally, ribavirin may induce a reduction in red blood cell counts and an increase in bilirubin levels. Table 5 shows the indications for use of ribavirin. The use of ribavirin is generally accepted for those infants with pre-existing moderate to severe cardiopulmo-

TABLE 5

Indications for Use of Ribavirin in Respiratory Syncytial Virus Infections* +

Use as early as possible in patients with

Severe cyanotic congenital heart disease

Severe bronchopulmonary dysplasia

Postoperative cardiac surgery

Use to avoid intubation in patients with

Moderate cyanotic congenital heart disease

Symptomatic bronchopulmonary dysplasia

Cystic fibrosis

T-cell immune defects

Use in any child who is consistently severely hypoxic $\left(\mathrm{PaO}_{2}<60 \mathrm{~mm} \mathrm{Hg}\right.$ in room air, $\left.\mathrm{PaCO}_{2}>40 \mathrm{~mm} \mathrm{Hg}\right)$

${ }^{*}$ Modified from the recommendations of the Committee on Infectious Diseases, the American Academy of Pediatrics: Pediatrics 1987; 79:475-478; and from Mclntosh: Pediatr Rev 1987; 9:191-196. tFurther studies are needed to clarify the role of ribavirin treatment in intubated patients requiring mechanical ventilation. nary disease and severely immunosuppressed patients. Pohl and colleagues ${ }^{184}$ studied RSV infections in pediatric liver transplant recipients. Infections within 20 days after transplantation and during exaggerated immunosuppression were most severe and were considered indications for ribavirin therapy. Ribavirin has not been recommended for patients with mechanical ventilation support, because the drug may precipitate within the ventilator apparatus. ${ }^{277}$ However, Smith and coworkers ${ }^{256}$ recently reported the safe and effective use of ribavirin in 14 young infants who needed mechanical ventilation for severe RSV infection.

Available data based on eight double-blind, placebo-controlled trials of the efficacy of ribavirin published during the last 9 years are summarized in Table 6. Of a total of 233 patients studied, 116 received ribavirin. Some benefits were observed in the clinical recovery phase, oxygen saturation, and viral shedding. Recently, it was suggested that early ribavirin therapy may reduce the morbidity of RSV infection in children with bronchopulmonary dysplasia or with congenital heart disease. ${ }^{283}$ Furthermore, the study in mechanically ventilated infants showed that ribavirin treatment reduced the time of mechanical ventilation, oxygen therapy, and hospital stay. In spite of these observed benefits, no significant reduction in overall cost for the care of patients with severe RSV infection was obtained. ${ }^{256}$

Ribavirin therapy is well tolerated and no acute toxicity has been reported. However, concern about possible long-term harmful effects, suppression of immunity, and possible risk to caretakers have been expressed. Use of surgical gloves and masks is recommended to minimize the potential exposure to the staff. Nurses known to be pregnant should avoid taking care of the patients receiving ribavirin therapy.

The use of ribavirin in previously healthy infants with RSV infection is a topic of great controversy. ${ }^{285,} 286$ The primary argument against use of the drug is that in the great majority of infants, even in those with severe lower respiratory tract RSV infection, the signs and symptoms of illness resolve uneventfully with supportive therapy alone within a few days. In addition, the clinical benefit appears to be modest at best. Most studies are based on a limited number of patients, have not included doubleblind, placebo controls, and often lack objective criteria when estimates of clinical efficacy are presented. No effects have been noted with respect to mortality, need for intensive care, and subsequent use of mechanical ventilation. In addition, the possible risks of exposure of health care personnel to ribavirin is still of concern. In spite of the shortage of 
TABLE 6

Double-Blind, Placebo-Controlled Studies on Ribavirin in the Treatment of Respiratory Syncytial Virus Infection

\begin{tabular}{|c|c|c|c|c|c|}
\hline & $\begin{array}{l}\text { No. of } \\
\text { Patients }\end{array}$ & Underlying Illness & $\begin{array}{c}\text { Criteria to Evaluate } \\
\text { Efficacy }\end{array}$ & $\begin{array}{c}\text { Response at the End } \\
\text { of Therapy }\end{array}$ & Ribavirin/Placebo \\
\hline \multirow[t]{3}{*}{ Hall et $\mathrm{al}^{278}$ (1983) } & \multirow[t]{3}{*}{33} & \multirow[t]{3}{*}{ None } & Clinical score & Improved & $0.8 / 1.7^{*}$ \\
\hline & & & Oxygen tension & Improved & $62 \mathrm{~mm} \mathrm{Hg} / 56 \mathrm{~mm} \mathrm{Hg}$ \\
\hline & & & Viral shedding & Improved & 2.9 days $/ 4.3$ days \\
\hline \multirow[t]{2}{*}{ Taber et al ${ }^{279}(1983)$} & \multirow[t]{2}{*}{26} & \multirow[t]{2}{*}{ None } & Clinical score & Improved & $0.6 / 1.3+$ \\
\hline & & & Viral shedding & No change & \\
\hline \multirow[t]{3}{*}{ Hall et $\mathrm{al}^{280}(1985)$} & \multirow[t]{3}{*}{26} & BPD & Clinical score & Improved & $55 \% / 29 \% \ddagger$ \\
\hline & & $\mathrm{CHD}$ & Oxygen tension & Improved & $73 \mathrm{~mm} \mathrm{Hg} / 58 \mathrm{~mm} \mathrm{Hg}$ \\
\hline & & None & Viral shedding & Improved & \\
\hline \multirow[t]{4}{*}{ Barry et al ${ }^{281}$ (1986) } & \multirow[t]{4}{*}{26} & \multirow[t]{4}{*}{ None } & Clinical score & Improved & \\
\hline & & & Heart rate/min & Decreased & $39 / 31$ \\
\hline & & & Respiratory rate/min & Decreased & $20 / 16$ \\
\hline & & & Viral shedding & No change & 3.5 days $/ 4$ days \\
\hline \multirow{3}{*}{$\begin{array}{l}\text { Rodriguez et } \mathrm{al}^{282} \\
\text { (1987) }\end{array}$} & \multirow[t]{3}{*}{30} & $\mathrm{BPD}$ & Clinical score & Improved & $0.6 / 1.2^{*}$ \\
\hline & & None & Oxygen saturation & Improved & \\
\hline & & & Viral shedding & No change & \\
\hline \multirow{5}{*}{$\begin{array}{l}\text { Groothuis et } \mathrm{al}^{283} \\
(1990)\end{array}$} & \multirow[t]{5}{*}{47} & $\mathrm{BPD}$ & Clinical score & Improved & $1.7 / 2.2 \S$ \\
\hline & & CHD & Oxygen saturation & Improved & $91 \% / 88 \%$ \\
\hline & & & $\begin{array}{l}\text { Need for mechanical } \\
\text { ventilation }\end{array}$ & No differences & \\
\hline & & & Need for ICU & No differences & \\
\hline & & & Need for oxygen & Decreased & \\
\hline \multirow[t]{5}{*}{ Edelson $^{284}(1990)$} & \multirow[t]{5}{*}{17} & BPD & Tachypnea & No difference & \\
\hline & & CHD & Oral feeding & No difference & \\
\hline & & & Hypoxemia, days & No difference & \\
\hline & & & $\begin{array}{l}\text { Need for supplemental } \\
\text { oxygen }\end{array}$ & Decreased & 2.2 days $/ 5.6$ days \\
\hline & & & $\begin{array}{l}\text { Need for mechanical } \\
\text { ventilation }\end{array}$ & Decreased & 0.5 days $/ 2.5$ days \\
\hline \multirow[t]{3}{*}{ Smith et $\mathrm{al}^{256}$ (1991) } & \multirow[t]{3}{*}{28} & $\begin{array}{l}\text { BPD } \\
\text { CHD }\end{array}$ & $\begin{array}{l}\text { Need for mechanical } \\
\text { ventilation }\end{array}$ & Decreased & 4.9 days $/ 9.9$ days \\
\hline & & $\begin{array}{l}\text { None } \\
\text { All mechanically }\end{array}$ & $\begin{array}{l}\text { Need for supplemental } \\
\text { oxygen }\end{array}$ & Decreased & 8.7 days/13.5 days \\
\hline & & ventilated & $\begin{array}{l}\text { Need for hospital stay } \\
\text { Hospital bill }\end{array}$ & $\begin{array}{l}\text { Decreased } \\
\$ 68,067 / \$ 77,666\end{array}$ & 13.3 days $/ 15.0$ days \\
\hline
\end{tabular}

$\overline{\mathrm{BPD}}=$ bronchopulmonary dysplasia; $\mathrm{CHD}=$ congenital heart disease; $\mathrm{ICU}=$ intensive care unit.

*Mean illness severity scores at the end of therapy. A score of 0 is normal and 4, most severe.

to is normal and 3, most severe illness.

$\ddagger$ Mean percent of improvement of clinical score.

$\$ 0$ is patient's normal baseline value and 10 , the worst severe illness.

our knowledge, however, ribavirin use has expanded, especially in the United States. In 1992, it was estimated that 200,000 patients with RSV infection have been treated with ribavirin. In Turku, Finland, during the 1991 to 1992 epidemic, 136 patients with RSV infection were hospitalized and no patient received ribavirin therapy. In contrast, in Galveston, Texas, 66 patients were admitted to a hospital and 14 were treated with ribavirin. Interestingly, a comparative study was performed in two centers in the United States, one using and the other one not using ribavirin. During three RSV seasons, 215 patients fulfilled the criteria of the American Academy of Pediatrics for ribavirin therapy; 108 patients were treated in one center and no one in the other. There were no differences in the need for oxygen therapy, need for mechanical ventilation, length of hospitalization, and mortality between the ribavirin-treated group and the group not treated with ribavirin. ${ }^{287,288}$ The effect of ribavirin therapy on hospital expenses is enormous since a single day of treatment costs $\$ 487$. As stated by many authors, it is clear that more carefully planned and performed studies are needed to delineate the indications of ribavirin in the treatment of severe RSV infections in previously healthy infants.

\section{Intravenous Gamma Globulin}

Studies in experimental animals and human infants suggested that RSV antibodies given in intravenous immunoglobulin (IVIG) may shorten the course and 
decrease the severity of RSV infection. ${ }^{289}$ Hemming and coworkers ${ }^{77}$ showed in a double-blind, placebocontrolled study that a single dose of $2 \mathrm{~g}$ of IVIG administered to children with RSV pneumonia or bronchiolitis significantly reduced the nasal shedding of RSV and improved the oxygen saturation, compared to placebo. The efficacy of IVIG is dependent on the neutralizing titer of anti-RSV antibody. ${ }^{79}$ Recently, a humanized monoclonal antibody to RSV was shown to be highly effective in vitro and in vivo. ${ }^{290}$ Further clinical studies with high-titer products are needed.

\section{Antibiotic Therapy}

Antibiotic therapy is given to at least $40 \%$ to $50 \%$ of patients hospitalized with RSV infections. ${ }^{203,291}$ Most often the indications include acute otitis media or possible bacterial-type pneumonia (see Secondary Bacterial Infections). However, in most patients, no concomitant bacterial infection can be demonstrated and there are no clear-cut indications for antibiotics in RSV infection in developed countries. Antibiotics are often ordered, however, because of the young age of the patients and difficulties in ruling out possible bacterial infection. Carlson and Orstavik ${ }^{291}$ showed that the active use of rapid RSV diagnosis reduced the use of antibiotics from $80 \%$ to $40 \%$. Two randomized studies demonstrated that routine antibiotic therapy has no benefits in the treatment of bronchiolitis. In the study by Field and colleagues, ${ }^{206}$ use of antibiotics such as ampicillin did not influence the outcome of bronchiolitis. The authors concluded that the antibiotics were used more to treat the physician's peace of mind than the patient's disease. Friis and coworkers ${ }^{207}$ studied over 100 children with bronchiolitis or pneumonia. Ampicillin or penicillin treatment did not change the clinical course of the illness. Mastoiditis developed in one patient in the control group. It can thus be concluded that antibiotics are used often unnecessarily in the treatment of RSV infections. House staff should have clear instructions for the use of antibiotics in patients with RSV infections.

\section{Prevention}

\section{Vaccines}

At present no safe and effective vaccine against RSV infection is available. Several different kinds of vaccines have been developed and some even tested in clinical trials. ${ }^{292-294} \mathrm{~A}$ formalin-inactivated RSV candidate vaccine studied in the 1960s induced virus-specific-neutralizing and complement-fixing antibodies. Paradoxically, however, during subsequent RSV infection a more severe pulmonary disease developed. Therefore, attenuated live-virus vaccines derived from wild-type virus grown in human diploid cells were developed. In clinical studies these vaccines were shown to be ineffective.

By passaging $\mathrm{RSV}$ at $26^{\circ} \mathrm{C}$, attenuated coldadapted RSV vaccine was developed but the vaccine induced mild respiratory disease in vaccinees. Temperature-sensitive mutants of RSV (virus is able to replicate at $37.0^{\circ} \mathrm{C}$ but not in higher temperatures) have also been tested. One and two mutant vaccines appeared to be either genetically unstable, pathogenic, or overattenuated with poor infectivity. A triple mutant RSV induces detectable anti-F and anti-G antibodies in adult volunteers and apparently has greater genetic stability than the earlier mutants. ${ }^{295}$ In experimental animals, recombinant vaccinia viruses or baculoviruses containing genes for $F$ and $G$ proteins have proved to be safe and effective. Finally, synthetic peptides of $F$ protein have been studied as candidate vaccines. Promising results have been obtained with an immunoaffinity purified $F$ protein vaccine, which is now undergoing clinical studies.

The development of effective and safe RSV vaccine has been difficult, since the vaccine needs to be given as early as the age of 1 month in order to have a significant impact on the frequency of disease. Unfortunately, maternally derived RSV antibodies exist at this time and may reduce its efficacy.

\section{Intravenous Gamma Globulin}

Animal studies have demonstrated that intravenous gamma globulin may prevent RSV-induced lower respiratory tract infection. Furthermore, favorable effects have been shown when IVIG was used in the treatment of RSV infection in human infants. ${ }^{77}$ Groothuis and associates ${ }^{78}$ studied IVIG in the prevention of RSV infection in 23 high-risk infants. These children with bronchopulmonary dysplasia or congenital heart disease received IVIG, 500 to 750 $\mathrm{mg} / \mathrm{kg}$, monthly from the age of 8 to 12 months. During the follow-up of 2 years, 12 children developed RSV infection. One child died; the other 11 infections were mild. The authors calculated that IVIG at $750 \mathrm{mg} / \mathrm{kg}$, with an RSV titer of $1: 4,000$ or greater, would be effective to prevent RSV infection if it is given monthly during the epidemic season. It is important to note that microneutralization assay should be used when screening plasma samples for highest protective activity. ${ }^{79}$ Further trials are under way to clarify the role of IVIG in the prevention of RSV infection. 


\section{Acknowledgments}

This study was supported by the National Institute of Allergy and Infectious Diseases (Al-15939-14) (P. L. O.) and The Academy of Finland (O. R.). We thank Dr Matti Waris and Dr Tasnee Chonmaitree for providing some of the epidemiologic data and Dr Constance Baldwin and Dr Roberto Garofalo for editorial assistance.

\section{References}

1. Stott EJ, Taylor G: Respiratory syncytial virus. Brief review. Arch Virol 1985; 84:1-52.

2. Hall CB: Respiratory syncytial virus, in Feigin RD, Cherry JD (eds): Textbook of Pediatric Infectious Diseases, ed 2. Philadelphia, W.B. Saunders Company, 1987, pp 1653-1676.

3. Anderson LJ: Paramyxoziridae: Respiratory syncytial virus, in Lennette EH, Halonen PH, Murphy FA (eds): Laboratory Diagnosis of Infectious Diseases. Principles and Practice, vol II. New York, Springer-Verlag, 1988, pp 540-570.

4. Welliver RC: Detection, pathogenesis, and therapy of respiratory syncytial virus infections. Clin Microbiol Rev 1988; 1:27-39.

5. Chanock RM, McIntosh K, Murphy BR, et al: Respiratory syncytial virus, in Evans AS (ed): Viral Infections of Humans. Epidemiology and Control, ed 3. New York, Plenum Medical Book Company, 1989, pp 525-544.

6. Hall CB: Respiratory syncytial virus, In Mandell GL, Douglas RG, Bennett JE (eds): Principles and Practice of Infectious Diseases, ed 3. New York, Churchill Livingstone, 1990, pp $1265-1279$.

7. McIntosh K, Chanock RM: Respiratory syncytial virus, in Fields BM, et al (eds): Virology, ed 2. New York, Raven Press Ltd, 1990, pp 1045-1072.

8. Belshe RB, Mufson MA: Respiratory syncytial virus, in Belshe RB (ed): Textbook of Human Virology. Chicago, MosbyYear Book, Inc, 1991, pp 388-407.

9. Pringle CG: The genetics of Paramyxovirus, in Kingsbury DW (ed): The Paramyxoviridae. New York, Plenum Press, 1991, pp $1-39$.

10. Galinski M: Annotated nucleotide and protein sequences for selected Paramyxoviridae, in Kingsbury DW (ed): The Paramyxoviruses. New York, Plenum Press, 1991, pp 537-568.

11. Collins PL: The molecular biology of human respiratory syncytial virus (RSV) of the genus Pneumovirus, in Kingsbury DW (ed): The Paramyxoviruses. New York, Plenum Press, 1991, pp 103-162.

12. Anderson LJ, Hierholzer JC, Tsou C, et al: Antigenic characterization of respiratory syncytial virus strains with monoclonal antibodies. I Infect Dis 1985; 151:626-633.

13. Mufson MA, Orvell C, Rafnar B, et al: Two distinct subtypes of human respiratory syncytial virus. J Gen Virol 1985; 66:2111-2124.

14. Walpita P, Mufson MA, Stanek RJ, et al: Distinguishing between respiratory syncytial virus subgroups by protein profile analysis. / Clin Microbiol 1991; 30:1030-1032.

15. Sullender WM, Anderson LJ, Anderson K, et al: Differentiation of respiratory syncytial virus subgroups with $\mathrm{CDNA}$ probes in a nucleic acid hybridization assay. I Clin Microbiol 1990; 28:1683-1687.

16. Sullender WM: Unpublished data, 1992.

17. Akerlind Stopner B: Respiratory syncytial virus. Subgroups. Thesis. Stockholm, Karolinska Institutet, 1991.

18. Sullender WM, Mufson MA, Anderson LJ, et al: Genetic diversity of the attachment protein of subgroup $B$ respiratory syncytial viruses. J Virol 1991; 65:5425-5434.
19. Storch GA, Anderson LJ, Park CS, et al: Antigenic and genomic diversity within group A respiratory syncytial virus. J Infect Dis 1991; 163:858-861.

20. Anderson LJ, Hendry RM, Pierik LT, et al: Multicenter study of strains of respiratory syncytial virus. J Infect Dis 1991; 163:687-692.

21. Glezen WP, Paredes A, Allison JE, et al: Risk of respiratory syncytial virus infection for infants from low-income families in relationship to age, sex, ethnic group, and maternal antibody level. J Pediatr 1981; 98:708-715.

22. Holberg CJ, Wright AL, Martinez FD, et al: Risk factors for respiratory syncytial virus-associated lower respiratory illnesses in the first year of life. Am / Epidemiol 1991; 133:1135-1151.

23. Avendano LF, Larranaga C, Palomino MA: Community- and hospital-acquired respiratory syncytial virus infections in Chile. Pediatr Infect Dis 1991; 10:564-568.

24. De Silva LM, Hanlon MG: Respiratory syncytial virus: A report of a 5-year study at a children's hospital. J Med Virol 1986; 19:299-305.

25. Glezen WP, Taber LH, Frank AL, et al: Risk of primary infection and reinfection with respiratory syncytial virus. Am J Dis Child 1986; 140:543-546.

26. Harsten G, Prellner K, Lofgren B, et al: Serum antibodies against respiratory tract viruses. A prospective three-year follow-up from birth. J Laryngol Otol 1989; 103:904-908.

27. Brussow $H$, Werchau $H$, Sidoti $J$, et al: Age-related prevalence of serum antibody to respiratory syncytial virus in Ecuadorian and German children. I Infect Dis 1991; 163: 679-680.

28. Falsey AR: Noninfluenza respiratory virus infection in longterm care facilities. Infect Control Hosp Epidemiol 1991; 12:602-608.

29. Henderson FW, Clyde WA Jr, Collier AM, et al: The etiologic and epidemiologic spectrum of bronchiolitis in pediatric practice. J Pediatr 1979; 95:183-190.

30. Fernald GW, Almond JR, Henderson FW: Cellular and humoral immunity in recurrent respiratory syncytial virus infections. Pediatr Res 1983; 17:753-758.

31. Denny FW, Collier AM, Henderson FW, et al: Infectious agents of importance in airways and parenchymal diseases in infants and children with particular emphasis on bronchiolitis. The epidemiology of bronchiolitis. Pediatr Res 1977; 11:234-236.

32. Selwyn BJ: The epidemiology of acute respiratory tract infection in young children: Comparison of findings from several developing countries. Rev Infect Dis 1990; 12(suppl 8): S870-S888.

33. Nohynek H, Eskola J, Laine E, et al: The causes of hospitaltreated acute lower respiratory tract infection in children. Am J Dis Child 1991; 145:618-622.

34. Ruuskanen O, Nohynek H, Ziegler $T$, et al: Pneumonia in childhood: Etiology and response to antimicrobial therapy. Eur I Clin Microbiol Infect Dis 1992;11:217-223.

35. Waris M, Meurman O, Mufson MA, et al: Shedding of infectious virus and virus antigen during acute infection with respiratory syncytial virus. J Med Virol 1992;38:111-116.

36. Kellner G, Popow-Kraupp T, Kundi M, et al: Contribution of rhinoviruses to respiratory viral infections in childhood: $\mathrm{A}$ prospective study in a mainly hospitalized infant population. J Med Virol 1988; 25:455-469.

37. Ruuskanen O: Unpublished data, 1992.

38. Orstavik I, Carlsen KH, Halvorsen K: Respiratory syncytial virus infections in Oslo 1972-1978. I. Virological and epidemiological studies. Acta Paediatr Scand 1980; 69:717-722.

39. Anderson LJ, Parker RA, Strikas RL: Association between 
respiratory syncytial virus outbreaks and lower respiratory tract deaths of infants and young children. I Infect Dis 1990; 161:640 646.

40. Waris M: Pattern of respiratory syncytial virus epidemics in Finland: Two-year cycles with alternating prevalence of groups A and B. I Infect Dis 1991; 163:464-469.

41. Cherian T, Simoes EA, Steinhoff MC, et al: Bronchiolitis in tropical South India. Am J Dis Child 1990; 144:1026-1030.

42. Martin AJ, Gardner PS, McQuillin J: Epidemiology of respiratory viral infection among paediatric inpatients over a sixyear period in North-East England. Lancet 1978; 2:1035-1038.

43. Monto AS, Ohmit S: Respiratory syncytial virus in a community population: Circulation of subgroups A and B since 1965. I Infect Dis 1990; 161:781-783.

44. McIntosh K, Halonen P, Ruuskanen O: Report of a workshop on respiratory viral infections: Epidemiology, diagnosis and prevention. Clin Infect Dis, in press.

45. Muelenaer PM, Henderson FW, Hemming VG, et al: Groupspecific serum antibody responses in children with primary and recurrent respiratory syncytial virus infection. $J$ Infect Dis 1991; 164:15-21.

46. Storch GA, Park CS, Dohner DE: RNA fingerprinting of respiratory syncytial virus using ribonuclease protection. I Clin Invest 1989; 83:1894-1902.

47. Cane PA, Pringle CR: Respiratory syncytial virus heterogeneity during an epidemic: Analysis by limited nucleotide sequencing ( $\mathrm{SH}$ gene) and restriction mapping ( $\mathrm{N}$ gene). J Gen Virol 1991; 72:349-357.

48. Cane PA, Matthews DA, Pringle CR: Analysis of relatedness of subgroup A respiratory syncytial viruses isolated worldwide. Virus Res 1992; 25:15-22.

49. Hall CB, Douglas RG Jr, Geiman JM: Possible transmission by fomites of respiratory syncytial virus. I Infect Dis 1980; 141:98-102.

50. Hall CB, Geiman JM, Biggar R, et al: Respiratory syncytial virus infections within families. $N$ Engl I Med 1976; 294:414-419.

51. Hall CB, Douglas RG, Geiman JM: Respiratory syncytial virus infections in infants: Quantitation and duration of shedding. I Pediatr 1976; 89:11-15.

52. McConnochie KM, Roghmann KJ: Parental smoking, presence of older siblings, and family history of asthma increase risk of bronchiolitis. Am J Dis Child 1986; 140:806-812.

53. Carlsen $\mathrm{KH}$, Larsen $\mathrm{S}$, Bjerve $\mathrm{O}$, et al: Acute bronchiolitis: Predisposing factors and characterization of infants at risk. Pediatr Pulmonol 1987; 3:153-160.

54. Anderson LJ, Parker RA, Strikas RA, et al: Day-care center attendance and hospitalization for lower respiratory tract illness. Pediatrics 1988; 82:300-308.

55. Laing I, Riedel F, Yap PL, et al: Atopy predisposing to acute bronchiolitis during an epidemic of respiratory syncytial virus. Br Med J 1982; 284:1070-1072.

56. Nagayama $Y$, Sakurai N, Nakahara $T$, et al: Allergic predisposition among infants with bronchiolitis. J Asthma 1987; 24:9-17

57. Sims DG, Gardner PS, Weightman D, et al: Atopy does not predispose to RSV bronchiolitis or postbronchiolitis wheezing. Br Med J 1981; 292:2086-2088.

58. Martinez FD, Morgan WJ, Wright AL, et al: Diminished lung function as a predisposing factor for wheezing respiratory syncytial illness in infants. $N$ Engl J Med 1988; 319: 1112-1117.

59. Hayes EB, Hurwitz ES, Schonberger LB, et al: Respiratory syncytial virus outbreak on American Samoa. Am J Dis Child 1989; 143:316-321

60. McConnochie KM, Roghmann KJ: Wheezing at 8 and 13 years: Changing importance of bronchiolitis and passive smoking. Pediatr Pulmonol 1989; 6:138-146.

61. Wright AL, Holberg C, Martinez FD, et al: Relationship of parental smoking to wheezing and nonwheezing lower respiratory tract illnesses in infancy. J Pediatr 1991; 118:207-214.

62. McIntosh K, Fishaut JM: Immunopathologic mechanisms in lower respiratory tract disease of infants due to respiratory syncytial virus. Prog Med Virol 1980; 26:94-118.

63. Smith JJ, Lemen RJ, Taussig LM: Mechanisms of viralinduced lower airway obstruction. Pediatr Infect Dis J 1987; 6:837-842.

64. Ogra PL: Allergy, respiratory tract infections and bronchial hyperreactivity. Pediatr Infect Dis J 1989; 8:347-352.

65. Kimman TG, Westenbrink F: Immunity to human and bovine respiratory syncytial virus. Arch Virol 1990; 112:1-25.

66. Garofalo R, Ogra PL: Mechanisms of disease with respiratory syncytial virus. Immunol Infect Dis 1991; 1:155-157.

67. Stark JM, Busse WW: Respiratory virus infection and airway hyperreactivity in children. Pediatr Allergy Immunol 1991; 2:95-110.

68. Gimenez HB, Keir HM, Cash P: In vitro enhancement of respiratory syncytial virus infection of U937 cells by human sera. J Gen Virol 1989; 70:89-96.

69. Krilov LR, Anderson LJ, Marcoux L, et al: Antibodymediated enhancement of respiratory syncytial virus infection in two monocyte/macrophage cell lines. I Infect Dis 1989; 160:777-782.

70. Ananaba GA, Anderson LJ: Antibody enhancement of respiratory syncytial virus stimulation of leukotriene production by a macrophagelike cell line. J Virol 1991; 65:5052-5060.

71. Toms GL, Scott R: Respiratory syncytial virus and the infant immune response. Arch Dis Child 1987; 62:544-546.

72. Murphy BR, Walsh EE: Formalin-inactivated respiratory syncytial virus vaccine induces antibodies to the fusion glycoprotein that are deficient in fusion-inhibiting activity. J Clin Microbiol 1988; 26:1595-1597.

73. Lamprecht CL, Krause HE, Mufson MA: Role of maternal antibody in pneumonia and bronchiolitis due to respiratory syncytial virus. I Infect Dis 1976; 134:211-217.

74. Hall CB, Walsh EE, Long CE, et al: Immunity to and frequency of reinfection with respiratory syncytial virus. J Infect Dis 1991; 163:693-698.

75. Graham BS, Bunton LA, Rowland J, et al: Respiratory syncytial virus infection in anti- $\mu$-treated mice. / Virol 1991; 65:4936-4942.

76. Connors M, Kulkarni AB, Collins PL, et al: Resistance to respiratory syncytial virus (RSV) challenge induced by infection with vaccinia virus recombinant expressing the RSV M2 protein (Vac-M2) is mediated by $\mathrm{CD}^{+} \mathrm{T}$ cells, while that induced by Vac-F or Vac-G recombinants is mediated by antibodies. I Virol 1992; 66:1277-1281.

77. Hemming VG, Rodriguez W, Kim HW, et al: Intravenous immunoglobulin treatment of respiratory syncytial virus infections in infants and young children. Antimicrob Agents Chemother 1987; 31:1882-1886.

78. Groothuis JR, Levin MI, Rodriguez W, et al: Use of intravenous gamma globulin to passively immunize high-risk children against respiratory syncytial virus: Safety and pharmacokinetics. Antimicrob Agents Chemother 1991; 35:1469-1473.

79. Siber GR, Leszczynski J, Pena-Cruz V, et al: Protective activity of a human respiratory syncytial virus immune globulin prepared from donors screened by microneutralization assay. I Infect Dis 1992; 165:456-463.

80. Kaul TN, Welliver RC, Wong DT, et al: Secretory antibody response to respiratory syncytial virus infection. Am I Dis Child 1981; 135:1013-1016. 
81. McIntosh K, Masters HB, Orr I, et al: The immunologic response to infection with respiratory syncytial virus in infants. J Infect Dis 1978; 138:24-32.

82. Welliver RC, Wong DT, Sun $M$, et al: The development of respiratory syncytial virus-specific $\operatorname{IgE}$ and the release of histamine in nasopharyngeal secretions after infection. $N$ Engl $)$ Med 1981; 305:841-846.

83. Bui RH, Molinaro GA, Kettering JD, et al: Virus-specific IgE and IgG4 antibodies in serum of children infected with respiratory syncytial virus. J Pediatr 1989; 110:87-90.

84. Welliver RC, Sun M, Rinaldo D, et al: Predictive value of respiratory syncytial virus-specific IgE responses for recurrent wheezing following bronchiolitis. I Pediatr 1986; 109: $776-780$.

85. Caswell SJ, Thomson AH, Ashmore SP, et al: Latent sensitisation to respiratory syncytial virus during acute bronchiolitis and lung function after recovery. Arch Dis Child 1990; 65:946-952.

86. Skoner DP, Fireman $\mathrm{P}$, Caliguiri L, et al: Plasma elevations of histamine and a prostaglandin metabolite in acute bronchiolitis. Am Rev Respir Dis 1990; 142:359-364.

87. Chonmaitree T, Lett-Brown MA, Grant JA: Respiratory viruses induce production of histamine-releasing factor by mononuclear leukocytes: A possible role in the mechanism of virus-induced asthma. J Infect Dis 1991; 164:592-594.

88. Stewart RS, Gershwin LJ: Role of IgE in the pathogenesis of bovine respiratory syncytial virus in sequential infections in vaccinated and nonvaccinated calves. Am J Vet Res 1989; 50:349-355.

89. Fishaut $\mathrm{M}$, Tubergen $\mathrm{D}$, McIntosh $\mathrm{K}$ : Cellular response to respiratory viruses with particular reference to children with disorders of cell-mediated immunity. I Pediatr 1980; 96:179-186.

90. Welliver RC, Kaul TN, Sun M, et al: Defective regulation of immune responses in respiratory syncytial virus infection. I Immunol 1984; 133:1925-1930.

91. Domurat F, Roberts NJ Jr, Walsh EE, et al: Respiratory syncytial virus infection of human mononuclear leukocytes in vitro and in vivo. I Infect Dis 1985; 152:895-902.

92. Welliver RC, Kaul A, Ogra PL: Cell-mediated immune response to respiratory syncytial virus infection: Relationship to the development of reactive airway disease. J Pediatr 1979; 94:370-375.

93. Scott R, Pullan CR, Scott M, et al: Cell-mediated immunity in respiralory syncylial virus disease. I Med Virol 1984, 13:105-114.

94. Levely ME, Bannow CA, Smith CW, et al: Immunodominant $T$-cell epitope on the $F$ protein of respiratory syncytial virus recognized by human lymphocytes. I Virol 1991; 65: 3789-3796

95. Paton AW, Paton JC, Lawrence AJ, et al: Rapid detection of respiratory syncytial virus in nasopharyngeal aspirates by reverse transcription and polymerase chain reaction amplification. I Clin Microbiol 1992; 30:901-904.

96. Graham BS, Bunton LA, Wright PF, et al: Role of T lymphocyte subsets in the pathogenesis of primary infection and rechallenge with respiratory syncytial virus in mice. J Clin Invest 1991; 88:1026-1033.

97. Isaacs D, Bangham CR, McMichael AJ: Cell-mediated cytotoxic response to respiratory syncytial virus in infants with bronchiolitis. Lancet 1987; 2:769-771.

98. Chiba $Y$, Higashidate $Y$, Suga $K$, et al: Development of cellmediated cytotoxic immunity to respiratory syncytial virus in human infants following naturally acquired infection. I Med Virol 1989; 28:133-139.

99. Cannon MJ, Openshaw PJ, Askonas BA: Cytotoxic T cells clear virus but augment lung pathology in mice infected with respiratory syncytial virus. $J$ Exp Med 1988; 168: $1163-1168$

100. Munoz JL, McCarthy CA, Clark ME, et al: Respiratory syncytial virus infection in C57BL/6 mice: Clearance of virus from the lungs with virus-specific cytotoxic $\mathrm{T}$ cells. $/ \dot{V}$ irol $1991 ; 65: 4494-4497$.

101. Nicholas JA, Rubino KL, Levely ME, et al: Cytolytic Tlymphocyte responses to respiratory syncytial virus: Effector cell phenotype and target proteins. I Virol 1990; 64: $4232-4241$.

102. Openshaw PJM, Anderson K, Wertz GW, et al: The 22,000kilodalton protein of respiratory syncytial virus is a major target for $\mathrm{K}^{\mathrm{d}}$-restricted cytotoxic $\mathrm{T}$ lymphocytes from mice primed by infection. I Virol 1990; 64:1683-1689.

103. Nicholas JA, Rubino KL, Levely ME, et al: Cytotoxic $\mathrm{T}$ cell activity against the 22-kDa protein of human respiratory syncytial virus (RSV) is associated with a significant reduction in pulmonary RSV replication. Virology 1991; 182:664-672.

104. McIntosh K: Interferon in nasal secretions from infants with viral respiratory tract infections. I Pediatr 1978; 93:33-36.

105. Chonmaitree T, Roberts NJ Jr, Douglas RG Jr, et al: Interferon production by human mononuclear leukocytes: Differences between respiratory syncytial virus and influenza viruses. Infect Immun 1981; 32:300-303.

106. Taylor CE, Webb MS, Milner AD, et al: Interferon alfa, infectious virus, and virus antigen secretion in respiratory syncytial virus infections of graded severity. Arch Dis Child 1989; 64:1656-1660.

107. Isaacs D: Production of interferon in respiratory syncytial virus bronchiolitis. Arch Dis Child 1989; 64:92-95.

108. Faden H, Kaul TN, Ogra PL: Activation of oxidative and arachidonic acid metabolism in neutrophils by respiratory syncytial virus antibody complexes: Possible role in disease. J Infect Dis 1983; 148:110-116.

109. Garofalo R, Welliver RC, Ogra PL: Concentrations of $\mathrm{LTB}_{4}$, $\mathrm{LTC}_{4}$ and $\mathrm{LTE}_{4}$ in bronchiolitis due to respiratory syncytial virus. Pediatr Allergy Immunol 1991; 2:30-37.

110. Garofalo R, Kimpen JLL, Welliver RC, et al: Eosinophil degranulation in the respiratory tract during naturally acquired respiratory syncytial virus infection. / Pediatr 1992; 120:28-32.

111. McCarthy DO, Domurat FM, Nichols JE, et al: Interleukin-1 inhibitor production by human mononuclear leukocytes and leukocyte subpopulations exposed to respiratory syncytial virus: Analysis and comparison with the response to influenza virus. I Leukoc Biol 1989; 46:189-198.

112. Salkind AR, McCarthy DO, Nichols JE, et al: Interleukin1-inhibitor activity induced by respiratory syncytial virus: Abrogation of virus-specific and alternate human lymphocyte proliferative responses. J Infect Dis 1991; 163:71-77.

113. Salkind AR, Nichols JE, Norbert JR Jr: Suppressed expression of ICAM-1 and LFA-1 and abrogation of leukocyte collaboration after exposure of human mononuclear leukocytes to respiratory syncytial virus in vitro. Comparison with exposure to influenza virus. J Clin Invest 1991; 88:505-511.

114. Nohynek $\mathrm{H}$, Teppo $\mathrm{M}$, Laine $\mathrm{E}$, et al: Serum tumor necrosis factor- $\alpha$ concentrations in children hospitalized for acute lower respiratory tract infection. I Infect Dis 1991; 163:1029-1032.

115. Panuska JR, Midulla F, Cirino NM, et al: Virus-induced alterations in macrophage production of tumor necrosis factor and prostaglandin $\mathrm{E}_{2}$. Am J Physiol 1990; 259:L396-L402.

116. Becker S, Quay J, Soukup J: Cytokine (tumor necrosis factor, IL-6, and IL-8) production by respiratory syncytial virusinfected human alveolar macrophages. I Immunol 1991; $147: 4307-4312$ 
117. Villani A, Cirino NM, Baldi E, et al: Respiratory syncytial virus infection of human mononuclear phagocytes stimulates synthesis of platelet-activating factor. I Biol Chem 1991; 266:5472-5479.

118. Panuska JR, Cirino NM, Midulla F, et al: Productive infection of isolated human alveolar macrophages by respiratory syncytial virus. J Clin lnvest 1990; 86:113-119.

119. Aherne W, Bird T, Court SD, et al: Pathological changes in virus infections of the lower respiratory tract in children. $J$ Clin Pathol 1970; 23:7-18.

120. Neilson KA, Yunis EJ: Demonstration of respiratory syncytial virus in an autopsy series. Pediatr Pathol 1990; 10:491-502.

121. Seidenberg J, Masters IB, Hudson I, et al: Disturbance in respiratory mechanics in infants with bronchiolitis. Thorax 1989; 44:660-667.

122. Krasinski K: Severe respiratory syncytial virus infection: Clinical features, nosocomial acquisition and outcome. Pediatr Infect Dis / 1985; 4:250-257.

123. Gardner PS, McQuillin J, Court SD: Speculation on pathogenesis in death from respiratory syncytial virus infection. Br Med J 1970; 1:327-330.

124. Carlsen $\mathrm{KH}$, Orstavik I, Halvorsen $\mathrm{K}$ : Viral infections of the respiratory tract in hospitalized children. A study from Oslo during a 90 months' period. Acta Paediatr Scand 1983; 72:53-58.

125. Galinovic G, Ugrcic I, Bozikov J: Respiratory syncytial virus infections in SR Croatia, Yugoslavia. Pediatr Pulmonol 1987; 3:304-308.

126. Mufson MA, Akerlind-Stopner B, Orvell C, et al: A singleseason epidemic with respiratory syncytial virus subgroup B2 during 10 epidemic years, 1978 to 1988. J Clin Microbiol 1991; 29:162-165.

127. Hall CB, Kopelman AE, Douglas RG Jr, et al: Neonatal respiratory syncytial virus infection. $N$ Engl $J$ Med 1979; 300:393-396.

128. Agah $\mathrm{R}$, Cherry JD, Garakian $\Lambda \mathrm{J}$, et al: Respiratory syncytial virus (RSV) infection rate in personnel caring for children with RSV infections. Routine isolation procedure vs routine isolation procedure supplemented by use of masks and goggles. Am J Dis Child 1987; 141:695-697.

129. Putto A, Ruuskanen O, Meurman O, et al: C-reactive protein in the evaluation of febrile illness. Arch Dis Child 1986; 61:24-29.

130. Shaw KN, Bell LM, Sherman NH: Outpatient assessment of infants with bronchiolitis. Am J Dis Child 1991; 145:151-155.

131. Kellner G, Popow-Kraupp T, Kundi $M$, et al: Clinical manifestations of respiratory tract infections due to respiratory syncytial virus and rhinoviruses in hospitalized children. Acta Paediatr Scand 1989; 78:390-394.

132. Wohl MEB, Chernick V: Bronchiolitis. Am Rev Respir Dis 1978; 118:759-781.

133. McConnochie KM: Bronchiolitis. What is the name? Am J Dis Child 1983; 137:11-13.

134. Schroeckenstein DC, Busse WW: Viral "bronchitis" in childhood: Relationship to asthma and obstructive lung disease. Semin Respir Infect 1988; 3:40-48.

135. McIntosh K: Bronchiolitis and asthma: Possible common pathogenetic pathways. I Allergy Clin Immunol 1976; 57:595-604.

136. Mulholland EK, Olinsky A, Shann FA: Clinical findings and severity of acute bronchiolitis. Lancet 1990; 335:1259-1261.

137. Welliver RC, Wong DT, Sun M, et al: Parainfluenza virus bronchiolitis. Epidemiology and pathogenesis. Am / Dis Child 1986; 140:34-40.

138. Hall CB, Hall WJ, Speers DM: Clinical and physiological manifestations of bronchiolitis and pneumonia. Outcome of respiratory syncytial virus. Am J Dis Child 1979; 133:798-802.

139. Wright PF: Bronchiolitis. Pediatr Rev 1986; 7:219 222.

140. Wildin SR, Chonmaitree T, Swischuk LE: Roentgenographic features of common pediatric viral respiratory tract infections. Am I Dis Child 1988; 142:43-46.

141. Coblentz CL, Babcook CJ, Alton D, et al: Observer variation in detecting the radiologic features associated with bronchiolitis. Invest Radiol 1991; 26:115-118.

142. Dawson KP, Long A, Kennedy J, et al: The chest radiograph in acute bronchiolitis. I Paediatr Child Health 1990; 26: 209-211.

143. McMillan JA, Tristram DA, Weiner LB, et al: Prediction of the duration of hospitalization in patients with respiratory syncytial virus infection: Use of clinical parameters. Pediatrics $1988 ; 81: 22-26$.

144. Green M, Brayer AF, Schenkman KA, et al: Duration of hospitalization in previously well infants with respiratory syncytial virus infection. Pediatr Infect Dis / 1989; 8:601-605.

145. Mertsola J, Ziegler T, Ruuskanen O, et al: Recurrent wheezy bronchitis and viral respiratory infections. Arch Dis Child 1991; 66:124-129.

146. McConnochie KM, Mark JD, McBride, JT, et al: Normal pulmonary function measurements and airway reactivity in childhood after mild bronchiolitis. J Pediatr 1985; 107:54-58.

147. Sly PD, Hibbert ME: Childhood asthma following hospitalization with acute viral bronchiolitis in infancy. Pediatr Pulmonol 1989; 7:153-158.

148. Carlsen $\mathrm{KH}$, Leegaard J, Larsen $\mathrm{S}$, et al: Nebulised beclomethasone dipropionate in recurrent obstructive episodes after acute bronchiolitis. Arch Dis Child 1988; 63:1428-1433.

149. Bisgaard H, Munck SL, Nielsen JP, et al: Inhaled budesonide for treatment of recurrent wheezing in early childhood. Lancet 1990; 336:649-651.

150. Haahtela $T$, Jarvinen $M$, Kava $T$, et al: Comparison of a $\beta_{2^{-}}$ agonist, terbutaline with an inhaled corticosteroid, budesonide, in newly detected asthma. $N$ Engl J Med 1991; 325:388-392.

151. Noble V, Ruggins NR, Everard ML, et al: Inhaled budesonide for chronic wheezing under 18 months of age. Arch Dis Child 1992; 67:285-288.

152. Committee on Infectious Diseases, the American Academy of Pediatrics, in Peter G (ed): Report of the Committee on Infectious Diseases, ed 12. Elk Grove Village, Ill, American Academy of Pediatrics, 1986, $p 479$.

153. Foucard T: The wheezy child. Acta Paediatr Scand 1985; $74: 172-178$

154. Carlsen $\mathrm{KH}$, Orstavik I: Bronchopulmonary obstruction in children with respiratory virus infection. Eur I Respir Dis 1984; 65:92 -98.

155. Wennergren G, Hansson S, Engstrom 1, et al: Characteristics and prognosis of hospital-treated obstructive bronchitis in children aged less than two years. Acta Paediatr Scand 1992; 81:40-45

156. Pattemore PK, Johnston SL, Bardin PG: Viruses as precipitants of asthma symptoms. I. Epidemiology. Clin Exp Allergy 1992; $22: 325-336$

157. Foucard T, Sjoberg O: A prospective 12-year follow-up study of children with wheezy bronchitis. Acta Paediatr Scand 1984; 73:577-583.

158. Wilson NM: Wheezy bronchitis revisited. Arch Dis Child 1989; 64:1194-1199.

159. Paisley JW, Lauer BA, McIntosh K, et al: Pathogens associated with acute lower respiratory tract infection in young children. Pediatr Infect Dis J 1984; 3:14-19.

160. Turner RB, Lande AE, Chase $P$, et al: Pneumonia in pediat- 
ric outpatients: Cause and clinical manifestations. J Pediatr 1987; 111:194-200.

161. Isaacs D: Problems in determining the etiology of community-acquired childhood pneumonia. Pediatr Infect Dis J 1989; 8:143-148

162. Claesson BA, Trollfors B, Brolin I, et al: Etiology of community-acquired pneumonia in children based on antibody responses to bacterial and viral antigens. Pediatr Infect Dis $J$ $1989 ; 8: 856-862$.

163. Rice RP, Loda F: A roentgenographic analysis of respiratory syncytial virus pneumonia in infants. Radiology 1966; 87:1021-1027.

164. Ruuskanen O, Putto A, Meurman O, et al: C-reactive protein in respiratory virus infections. I Pediatr 1985; 107: $97-100$.

165. Friis B, Eiken M, Hornsleth A, et al: Chest X-ray appearances in pneumonia and bronchiolitis. Acta Paediatr Scand 1990; 79:219-255.

166. Quinn SF, Erickson S, Oshman D, et al: Lobar collapse with respiratory syncytial virus pneumonitis. Pediatr Radiol 1985; 15:229-230.

167. Abzug MJ, Beam AC, Gyorkos EA, et al: Viral pneumonia in the first month of life. Pediatr Infect Dis J 1990; 9:881-885.

168. Unger A, Tapia L, Minnich LL, et al: Atypical neonatal respiratory syncytial virus infection. J Pediatr 1982; 100:762-764.

169. Dagan R, Hall CB, Powell KR, et al: Epidemiology and laboratory diagnosis of infection with viral and bacterial pathogens in infants hospitalized for suspected sepsis. I Pediatr 1.989; 115:351-356.

170. Anas N, Boettrich C, Hall CB, et al: The association of apnea and respiratory syncytial virus infection in infants. J Pediatr 1982; 101:65-68.

171. Church NR, Anas NG, Hall CB, et al: Respiratory syncytial virus-related apnea in infants. Am I Dis Child 1984; 138:247-250.

172. Pickens DL, Schefft GL, Storch GA, et al: Characterization of prolonged apneic cpisodes associated with respiratory syncytial virus infection. Pediatr Pulmonol 1989; 6:195-201.

173. Lindgren C, Jing L, Graham B, et al: Respiratory syncytial virus infection reinforces reflex apnea in young lambs. Pediatr Res 1992; 31:381-385.

174. Aylward RB, Burdge DR: Ribavirin therapy of adult respiratory syncytial virus pneumonitis. Arch Intern Med 1991; 151:2303-2304.

175. Guidry GG, Black-Payne CA, Payne DK, et al: Respiratory syncytial virus infection among intubated adults in a university medical intensive care unit. Chest 1991; 100:1377-1384.

176. Englund JA, Sullivan CJ, Jordan MC, et al: Respiratory syncytial virus infection in immunocompromised adults. Ann Intern Med 1988; 109:203-208.

177. Englund JA, Anderson LJ, Rhame FS: Nosocomial transmission of respiratory syncytial virus in immunocompromised adults. J Clin Microbiol 1991; 29:115-119.

178. Hertz MI, Englund JA, Snover D, et al: Respiratory syncytial virus-induced acute lung injury in adult patients with bone marrow transplants: A clinical approach and review of the literature. Medicine 1989; 68:269-281.

179. Meert K, I Jeidemann S, Abella B, et al: Does premalurity alter the course of respiratory syncytial virus infection? Crit Care Med 1990; 18:1357-1359.

180. Groothuis JR, Gutierrez KM, Lauer BA: Respiratory syncytial virus infection in children with bronchopulmonary dysplasia. Pediatrics 1988; 82:199-203.

181. MacDonald NE, Hall CB, Suffin SC, et al: Respiratory syncytial viral infection in infants with congenital heart disease. $N$ Engl J Med 1982; 307:397-400.
182. Ogra PL, Patel JP: Respiratory syncytial virus infection and the immunocompromised host. Pediatr Infect Dis J 1988; 7:246-249.

183. Hall CB, Powell KR, MacDonald NE, et al: Respiratory syncytial viral infection in children with compromised immune function. N Engl J Med 1986; 315:77-81.

184. Pohl C, Green M, Wald ER, et al: Respiratory syncytial virus infections in pediatric liver transplant recipients. I Infect Dis 1992; 165:166-169.

185. Abman SH, Ogle JW, Butler-Simon N, et al: Role of respiratory syncytial virus in early hospitalizations for respiratory distress of young infants with cystic fibrosis. J Pediatr 1988; 113:826-830.

186. Chandwani S, Borkowsky W, Krasinski K, et al: Respiratory syncytial virus infection in human immunodeficiency virusinfected children. J Pediatr 1990; 117:251-254.

187. Pahl E, Gidding SS: Echocardiographic assessment of cardiac function during respiratory syncytial virus infection. Pediatrics $1988 ; 81: 830-834$.

188. Sreeram N, Watson JG, Hunter S: Cardiovascular effects of acute bronchiolitis. Acta Paediatr Scand 1991; 80:133-136.

189. McConnochie KM, Hall CB, Walsh EE, et al: Variation in severity of respiratory syncytiai virus intections with subtype. J Pediatr 1990; 117:52-62.

190. Hall CB, Walsh EE, Schnabel KC, et al: Occurrence of groups $A$ and $B$ of respiratory syncytial virus over 15 years: Associated epidemiologic and clinical characteristics in hospitalized and ambulatory children. I Infect Dis 1990; 162:1283-1290.

191. Taylor CE, Morrow S, Scott M, et al: Comparative virulence of respiratory syncytial virus subgroups $\mathrm{A}$ and $\mathrm{B}$. Lancet 1989; 1:777-778.

192. Salomon HE, Avial MM, Cerqueiro MC, et al: Clinical and epidemiologic aspects of respiratory syncytial virus antigenic variants in Argentinian children. J Infect Dis 1991; 163:1167.

193. Russi JC, Chiparelli H, Montano A, et al: Respiratory syncytial virus subgroups and pneumonia in children. Lancet 1989; 2:1039-1040.

194. Hendry RM, Pierik LT, McIntosh K: Prevalence of respiratory syncytial virus subgroups over six consecutive outbreaks: 1981-1987. J Infect Dis 1989; 160:185-190.

195. Stark JM, Fatemi SH, Amini SB, et al: Occurrence of respiratory syncytial virus subtypes in hospitalized children in Cleveland, Ohio from 1985 to 1988. Pediatr Pulmonol 1991; 11:98-102.

196. Tsutsumi H, Onuma M, Nagai K, et al: Clinical characteristics of respiratory syncytial virus (RSV) subgroup infections in Japan. Scand J Infect Dis 1991; 23:671-674.

197. Ruuskanen O, Arola M, Heikkinen T, et al: Viruses in acute otitis media: Increasing evidence for clinical significance. Pediatr Infect Dis J 1991; 10:425-427.

198. Ruuskanen O, Arola M, Putto-Laurila A, et al: Acute otitis media and respiratory virus infections. Pediatr Infect Dis I 1989; 8:94-99.

199. Sarkkinen $\mathrm{H}$, Ruuskanen $\mathrm{O}$, Meurman $\mathrm{O}$, et al: Identification of respiratory virus antigens in middle ear fluids of children with acute otitis media. J Infect Dis 1985; 151:444-448.

200. Arola M, Ziegler T, Ruuskanen O: Respiratory virus infection as a cause of prolonged symptoms in acute otitis media. J Pediatr 1990; 116:697-701.

201. Chonmaitree T, Owen MJ, Howie VM: Respiratory viruses interfere with bacteriologic response to antibiotic in children with acute otitis media. J Infect Dis 1990; 162:546-549.

202. Chonmaitree T, Owen MJ, Patel JA, et al: Effect of viral respiratory tract infection on outcome of acute otitis media. I Pediatr 1992; 120:856-862. 
203. Hall CB, Powell KR, Schnabel KC, et al: Risk of secondary bacterial infection in infants hospitalized with respiratory syncytial viral infection. I Pediatr 1988; 113:266 271.

204. Timmons OD, Yamauchi T, Collins SR, et al: Association of respiratory syncytial virus and Streptococcus pneumoniae infection in young infants. Pediatr Infect Dis J 1987; 6:1134-1135.

205. Tristram DA, Miller RW, McMillan JA, et al: Simultaneous infection with respiratory syncytial virus and other respiratory pathogens. Am J Dis Child 1988; 142:834-836.

206. Field CM, Connolly JH, Murtagh G, et al: Antibiotic treatment of epidemic bronchiolitis-A double-blind trial. Br Med I 1966; 1:83-85.

207. Friis B, Andersen P, Brene E, et al: Antibiotic treatment of pneumonia and bronchiolitis. A prospective randomised study. Arch Dis Child 1984; 59:1038-1045.

208. Ghafoor A, Nomani NK, Ishaq Z, et al: Diagnoses of acute lower respiratory tract infections in children in Rawalpindi and Islamabad, Pakistan. Rev Infect Dis 1990; 12(suppl 8):S907-S914.

209. Nelson WL, Hopkins RS, Roe MH, et al: Simultaneous infection with Bordetella pertussis and respiratory syncytial virus in hospitalized children. Pediatr Infect Dis / 1986; 5:540-544.

210. Hietala J, Uhari $M$, Tuokko $H$ : Mixed bacterial and viral infections are common in children. Pediatr Infect Dis J 1989; 8:683-686.

211. Korppi $M$, Leinonen $M$, Koskela $M$, et al: Bacterial coinfection in children hospitalized with respiratory syncytial virus infection. Pediatr Infect Dis J 1989; 8:687-692.

212. Graman PS, Hall CB: Nosocomial viral respiratory infection. Semin Respir Infect 1989;4:253-260.

213. Goldmann DA: Nosocomial viral infections: Recent developments and new strategies. Eur J Clin Microbiol Infect Dis 1989; 8:75-81.

214. Takimoto $\mathrm{CH}, \mathrm{Cram} \mathrm{DL}$, Root RK: Respiratory syncytial virus infections on an adult ward. Arch Intern Med 1991; 151:706-708.

215. Krasinski K, LaCouture R, Holzman RS, et al: Screening for respiratory syncytial virus and assignment to a cohort at admission to reduce nosocomial transmission. I Pediatr 1990; 116:894-898

216. Isaacs D, Dickson H, O'Callaghan C, et al: Handwashing and cohorting in prevention of hospital acquired infections with respiratory syncytial virus. Arch Dis Child 1991; 66:227-231.

217. Platt J, Bucknall RA: The disinfection of respiratory syncytial virus by isopropanol and chlorhexidine-detergent handwash. I Hosp Infect 1985; 6:89-94.

218. Hall CB, Douglas RG: Nosocomial respiratory syncytial viral infections. Should gowns and masks be used? Am J Dis Child $1981 ; 135: 512-515$.

219. Murphy D, Todd JK, Choa RK, et al: The use of gowns and masks to control respiratory illness in pediatric hospital personnel. J Pediatr 1981; 99:746-750.

220. LeClair JM, Freeman J, Sullivan BF, et al: Prevention of nosocomial respiratory syncytial virus infections through compliance with glove and gown isolation precautions. $N$ Engl $]$ Med 1987; 317:329-334.

221. Snydman DR, Greer C, Meissner HC, et al: Prevention of nosocomial transmission of respiratory syncytial virus in a newborn nursery. Infect Control Hosp Epidemiol 1988; 9:105-108.

222. Mcintosh K: Respiratory syncytial virus infections in infants and children: Diagnosis and treatment. Pediatr Rev 1987; 9:191-196.

223. Williams $\mathrm{AL}$, Uren EC, Bretherton L: Respiratory viruses and sudden infant death. Br Med J 1984; 299:1491-1493.
224. Ogra PL, Ogra SS, Coppola PR: Secretory component and sudden-infant-death syndrome. Lancet 1975; 2:387-390.

225. Meurman $\mathrm{O}$, Ruuskanen $\mathrm{O}$, Sarkkinen $\mathrm{H}$, et al: Immunoglobulin class-specific antibody response in respiratory syncytial virus infection measured by enzyme immunoassay. I Med Virol 1984; 14:67-72.

226. Welliver RC, Kaul TN, Putnam TI, et al: The antibody response to primary and secondary infection with respiratory syncytial virus: Kinetics of class-specific responses. J Pediatr 1980; 96:808-813.

227. Popow-Kraupp T, Lakits E, Kellner G, et al: Immunoglobulin-class-specific immune response to respiratory syncytial virus structural proteins in infants, children, and adults. $J$ Med Virol 1989; 27:215-223.

228. Meddens MJ, Herbrink P, Lindeman J, et al: Serodiagnosis of respiratory syncytial virus (RSV) infection in children as measured by detection of RSV-specific immunoglobulins $G$, $\mathrm{M}$ and $\mathrm{A}$ with enzyme-linked immunosorbent assay. / Clin Microbiol 1990; 28:152-155.

229. Wagner DK, Graham BS, Wright PF, et al: Serum immunoglobulin $G$ antibody subclass response to respiratory syncytial virus $\mathrm{F}$ and $\mathrm{G}$ glycoproteins after primary infection. I Clin Microbiol 1986; 24:304-306.

230. Okamulo $Y$, Brodsky L, Bernstein JM, et al: Characteristics of in vitro production of mucosal antibody to respiratory syncytial virus in tonsillar tissue lymphocytes. Clin Immunol Immunopathol 1988; 49:299-307.

231. Vainionpaa $R$, Meurman $O$, Sarkkinen H: Antibody response to respiratory syncytial virus structural proteins in children with acute respiratory syncytial virus infection. J $\mathrm{Vi}$ rol 1985; 53:976-979.

232. Hendry RM, Burns JC, Walsh EE, et al: Strain-specific serum antibody responses in infants undergoing primary infection with respiratory syncytial virus. I Infect Dis 1988; 157: 640-647.

233. Welliver RC, Sun M, Hildreth SW, et al: Respiratory syncytial virus-specific antibody responses in immunoglobulin $A$ and $E$ isotypes to the $F$ and $G$ proteins and to intact virus after natural infection. J Clin Microbiol 1989; 27:295-299.

234. Subbarao EK, Dietrich MC, DeSierra TM, et al: Rapid detection of respiratory syncytial virus by a biotin-enhanced immunoassay: Test performance by laboratory technologists and house staff. Pediatr Infect Dis J 1989; 8:865-869.

235. Kellogg JA: Culture vs direct antigen assays for detection of microbial pathogens from lower respiratory tract specimens suspected of containing the respiratory syncytial virus. Arch Pathol Lab Med 1991; 115:451-458.

236. Smith MC, Creutz C, Huang YT: Detection of respiratory syncytial virus in nasopharyngeal secretions by shell vial technique. I Clin Microbiol 1991; 29:463 - 465.

237. Meurman O, Sarkkinen H, Ruuskanen O, et al: Diagnosis of respiratory syncytial virus infection in children: Comparison of viral antigen detection and serology. I Med Virol 1984; 14:61-65.

238. Sullender WM, Wertz GW: Synthetic oligonucleotide probes differentiate respiratory syncytial virus subgroups in a nucleic acid hybridization assay. I Clin Microbiol 1991; 29:1255-1257.

239. Cubie HA, Inglis JM, McGowan AM: Detection of respiratory syncytial virus antigen and nucleic acid in clinical specimens using synthetic oligonucleotides. J Virol Methods 1991; 34:27-35.

240. Okamoto Y, Shirotori K, Kudo K, et al: Genomic sequences of respiratory syncytial virus in otitis media with effusion. Lancet 1991; 338:1025-1026.

241. Johnston SLG, Siegel CS: Evaluation of direct immunofluo- 
rescence, enzyme immunoassay, centrifugation culture, and conventional culture for the detection of respiratory syncytial virus. I Clin Microbiol 1990; 28:2394-2397.

242. VanBeers D, De Foor M, DiCesare L, et al: Evaluation of a commercial enzyme immunomembrane filter assay for detection of respiratory syncytial virus in clinical specimens. Eur J Clin Microbiol Infect Dis 1991; 10:1073-1076.

243. Wren CG, Bate BJ, Masters HB, et al: Detection of respiratory syncytial virus antigen in nasal washings by Abbot TestPack enzyme immunoassay. I Clin Microbiol 1990; 28:1395-1397.

244. Ahluwalia GS, Hammond GW: Comparison of cell culture and three enzyme-linked immunosorbent assays for the rapid diagnosis of respiratory syncytial virus from nasopharyngeal aspirate and tracheal secretion specimens. Diagn Mi crobiol Infect Dis 1988; 9:187-192.

245. Thomas EE, Book LE: Comparison of two rapid methods for detection of respiratory syncytial virus (RSV) (TestPack RSV and Ortho RSV ELISA) with direct immunofluorescence and virus isolation for the diagnosis of pediatric RSV infection. I Clin Microbiol 1991; 29:632-635.

246. Christensen ML, Flanders R: Comparison of the Abbot and Ortho enzyme immunoassays and cell culture for the detection of respiratory syncytial virus in nasopharyngeal specimens. Diagn Microbiol Infect Dis 1988; 9:245-250.

247. Freymuth F, Brooks W, Petitjean J, et al: Evaluation of an enzyme membrane immunoassay (Directigen RSV) for the rapid diagnosis of respiratory syncytial virus infections. Pathol Biol 1991; 39:283-286

248. Rothbarth PH, Hermus C, Schrijnemakers P: Reliability of two new test kits for rapid diagnosis of respiratory syncytial virus infection. J Clin Microbiol 1991; 29:824-826.

249. Halstead DC, Todd S, Fritch G: Evaluation of five methods for respiratory syncytial virus detection. I Clin Microbiol 1990; 28:1021-1025.

250. Swierkosz EM, Flanders R, Melvin L, et al: Evaluation of the Abbot TESTPACK RSV enzyme immunoassay for detection of respiratory syncytial virus in nasopharyngeal swab specimens. J Clin Microbiol 1989; 27:1151-1154.

251. Waris M, Ziegler T, Kivivirta M, et al: Rapid detection of res piratory syncytial virus and influenza $A$ virus in cell cultures by immunoperoxidase staining with monoclonal antibodies. I Clin Microbiol 1990; 28:1159-1162.

252. Rosen LM, Yamamoto LG, Wiebe RA: Pulse oximetry to identify a high-risk group of children with wheezing. Am I Emerg Med 1989; 7:567-570.

253. Outwater KM, Crone RK: Management of respiratory failure in infants with acute viral bronchiolitis. Am I Dis Child 1984 138:1071-1075.

254. Frankel LR, Lewiston NJ, Smith DW, et al: Clinical observations on mechanical ventilation for respiratory failure in bronchiolitis. Pediatr Pulmonol 1986; 2:307-311.

255. Lebel MH, Gauthier M, Lacroix J, et al: Respiratory failure and mechanical ventilation in severe bronchiolitis. Arch Dis Child 1989; 64:1431-1437.

256. Smith DW, Frankel LR, Mathers LH, et al: A controlled trial of aerosolized ribavirin in infants receiving mechanical ventilation for severe respiratory syncytial virus infection. $N$ Engl I Med 1991; 325:24-29.

257. Steinhorn RH, Green TP: Use of extracorporeal membrane oxygenation in the treatment of respiratory syncytial virus bronchiolitis: The national experience, 1983-1988. I Pediatr 1990; 116:338-342.

258. Van Steensel-Moll HA, Hazelzet JA, Van Der Voort E, et al: Excessive secretion of antidiuretic hormone in infections with respiratory syncytial virus. Arch Dis Child 1990; 65:1237-1239

259. Gozal D, Colin AA, Jaffe M, et al: Water, electrolyte, and endocrine homeostasis in infants with bronchiolitis. Pediatr Res 1990; 27:204-209.

260. Milner AD, Murray M: Acute bronchiolitis in infancy: Ireatment and prognosis. Thorax 1989; 44:1-5.

261. Nahata MC, Johnson JA, Powell DA: Management of bronchiolitis. Clin Pharmacol 1985; 4:297-303.

262. Ho L, Collis G, Landau LI, et al: Effect of salbutamol on oxygen saturation in bronchiolitis. Arch Dis Child 1991; 66:1061-1064.

263. Wang EE, Milner R, Allen U, et al: Bronchodilators for treatment of mild bronchiolitis: A factorial randomised trial. Arch Dis Child 1992; 67:289-293.

264. Lowell DI, Lister $\mathrm{G}$, Von Koss $\mathrm{H}$, et al: Wheezing in infants: The response to epinephrine. Pediatrics 1987; 79:939-945.

265. Mallory GB, Motoyama EK, Koumbourlis AC, et al: Bronchial reactivity in infants in acute respiratory failure with viral bronchiolitis. Pediatr Pulmonol 1989; 6:253-259.

266. Schuh S, Canny G, Reisman JJ, et al: Nebulized albuterol in acute bronchiolitis. I Pediatr 1990; 117:633-637.

267. Klassen TP, Rowe PC, Sutcliffe T, et al: Randomized trial of salbutamol in acute bronchiolitis. I Pediatr 1991; 118:807-811.

268. Kraemer R, Frey U, Sommer CW, et al: Short-term effect of albuterol, delivered via a new auxiliary device, in wheezy infants. Am Rev Respir Dis 1991; 144:347-351.

269. Tal A, Sanchez I, Pasterkamp H: Respirosonography in infants with acute bronchiolitis. Am J Dis Child 1991; 145:1405-1410

270. Alario AJ, Lewander WJ, Dennehy $P$, et al: The efficacy of nebulized metaproterenol in wheezing infants and young children. Am / Dis Child 1992; 146:412-418.

271. Schuh S, Parkin P, Rajan A, et al: High- versus low-dose, frequently administered, nebulized albuterol in children with severe, acute asthma. Pediatrics 1989; 83:513-518.

272. Springer C, Bar-Yishay E, Uwayyed K, et al: Corticosteroids do not affect the clinical or physiological status of infants with bronchiolitis. Pediatr Pulmonol 1990; 9:181-185.

273. Committee on Drugs: Should steroids be used in treating bronchiolitis? Pediatrics 1970; 46:640-642.

274. Tal A, Bavilski C, Yohai D, et al: Dexamethasone and salbutamol in the treatment of acute wheezing in infants. Pediatrics 1983; 71:13-18.

275. Gilbert BE, Knight V: Biochemistry and clinical applications of ribavirin. Antimicrob Agents Chemother 1986; 30:201-205.

276. Englund JA, Piedra PA, Jefferson LS, et al: High-dose, shortduration ribavirin aerosol therapy in children with suspected respiratory syncytial virus infection. I Pediatr 1990; 117: 313-320.

277. Committee on Infectious Diseases, The American Academy of Pediatrics: Ribavirin therapy of respiratory syncytial virus. Pediatrics 1987; 79:475-478.

278. Hall CB, McBride JT, Walsh EE, et al: Aerosolized ribavirin treatment of infants with respiratory syncytial viral infection. A randomized double-blind study. $N$ Engl / Med 1983; 308:1443-1447

279. Tabor LH, Knight V, Gilbert BE, et al: Ribavirin aerosol treatment of bronchiolitis associated with respiratory syncytial virus infection in infants. Pediatrics 1983; 72:613-618.

280. Hall CB, McBride JI, Gala CL, et al: Ribavirin treatment of respiratory syncytial viral infection in infants with underlying cardiopulmonary disease. JAMA 1985; 254:3047-3051.

281. Barry W, Cockburn F, Cornall R, et al: Ribavirin aerosol for acute bronchiolitis. Arch Dis Child 1986; 61:593-597. 
282. Rodriguez WJ, Kim HW, Brandt CD, et al: Aerosolized ribavirin in the treatment of patients with respiratory syncytial virus disease. Pediatr Infect Dis J 1987; 6:159-163.

283. Groothuis JR, Woodin KA, Katz R, et al: Early ribavirin treatment of respiratory syncytial viral infection in high-risk children. I Pediatr 1990; 117:792-798.

284. Edelson PJ: Clinical studies with ribavirin. Pediatr Infect Dis J 1990; 9:S71-S73.

285. Isaacs D, Moxon ER, Harvey D, et al: Ribavirin in respiratory syncytial virus infection. A double blind placebo controlled trial is needed. Arch Dis. Child 1988; 63:986-990.

286. Wald ER, Dashefsky B, Green M: In re ribavirin: A case of premature adjudication? J Pediatr 1988; 112:154-158.

287. ICN Pharmaceuticals, Inc.: Personal communication, 1992.

288. Wheeler JG, Wofford JL, Turner RB: Two center comparison of respiratory syncytial virus infected patients treated with or without ribavirin. Clin Res 1991; 39:862A.

289. Hemming VG, Prince GA: Immunoprophylaxis of infections with respiratory syncytial virus: Observations and hypothesis. Rev Infect Dis 1990; 12(suppl 4):S470-S475.
290. Taylor G, Furze J, Tempest PR, et al: Humanised monoclonal antibody to respiratory syncytial virus. Lancet 1991; 337:1411- 1412.

291. Carlsen $\mathrm{KH}$, Orstavik I: Respiratory syncytial virus infection in Oslo 1972-1978. II. Clinical and laboratory studies. Acta Paediatr Scand 1980; 69:723-729.

292. Murphy BR, Prince GA, Collins PL, et al: Current approaches to the development of vaccines effective against parainfluenza and respiratory syncytial viruses. Virus Res 1988; 11:1-15.

293. Ogra PL, Garofalo R: Secretory antibody response to viral vaccines. Prog Med Virol 1990; 37:156-189.

294. Toms GL: Vaccination against respiratory syncytial virus: Problems and progress. FEMS Microbiol Immunol 1991; 73:243-256.

295. Pringle CR, Filipiuk AH, Robinson BS, et al: Immunogenicity and pathogenicity of a triple temperature-sensitive modified respiratory syncytial virus in adult volunteers. Vaccine, in press 